\title{
The Principle of Consumer Utility: A Contemporary Theory of the Bankruptcy Discharge
}

\author{
Michael D. Sousa*
}

\section{INTRODUCTION}

But at present the laws of bankruptcy are considered as laws... founded on the principles of humanity as well as justice: and to that end they confer some privileges, not only on the creditors, but also on the bankrupt or debtor himself.

For better or for worse, we live in an age of consumer credit. To that end, it is beyond contention that the use of consumer credit has become a part of American culture. ${ }^{2}$ Indeed, during the course of the twentieth century, attitudes about debt and consumption shifted from moral shame to resounding acceptance. ${ }^{3}$ Many believe quite firmly that the escalation in the utilization of consumer credit during the past four or five decades is the result of a loss of personal self-discipline and the rise of materialistic cupidity by the average consumer. ${ }^{4}$ Despite this belief, however, borrowing and lending by American consumers have been prevalent practices since the late nineteenth century. ${ }^{5}$ But it is in the past few decades that the average American has become indebted and overextended like never before. And while it would certainly be disingenuous to suggest that a segment of American consumers have not attempted to live avariciously beyond their practical means, in today's

\footnotetext{
* Assistant Professor of Law, University of Denver Sturm College of Law. The author would like to thank Professor Alan Chen and Professor Richard Lieb for providing comments on an earlier draft of this Article.

1. 2 William Blackstone, COMmentaries $* 471$.

2. For a historical analysis of the rise of consumer credit in the United States, see generally lendol Calder, Financing the American Dream: a Cultural History of Consumer CREDIT (1999).

3. $I d$. at 20 .

4. Id. at 33

5. Id. at 39. According to the research of Lendol Calder, "[t]he 1890 census figure would apportion to each household in the United States about $\$ 880$ of debt." Id. at 40 . This amount is striking, particularly because the average annual wage of non-farm workers for the year 1890 amounted to $\$ 475$. Id.
} 
economic times " $[\mathrm{t}]$ he significance of consumer credit is now measured by the fact that for [both lower and] middle-class people it has become virtually impossible to live the American dream without access to" consumer credit of all stripes. ${ }^{6}$ Consequently, the use of consumer credit has become a necessity of everyday life, a mechanism for a family to live beyond the bounds of poverty. Simply put, for America in 2009, credit underscores everyday life. ${ }^{7}$ In this national economy, "most low- and moderate-income people borrow to live on their income. They are not borrowing to keep up with the Joneses; they are borrowing to stay afloat, to keep up with payments for housing, food, transportation, and health care."

Though the United States economy has been growing for the past several decades, the majority of individuals have little to show from such progress. ${ }^{9}$ Various economic indicators corroborate this assertion. For instance, as of 2004, the median wage in the United States was the same as it was thirty years before. ${ }^{10}$ Further, the "real income of the bottom 90 percent of American taxpayers has declined steadily: they earned $\$ 27,060$ in real dollars in $1979, \$ 25,646$ in 2005." 11 And, "[w]hile median net wealth grew from $\$ 69,465$ to $\$ 93,001$ from 1989 to 2004, it was outpaced by consumer debt, which more than doubled during the same period, from $\$ 22,000$ to $\$ 55,300 . " 12$

By all measures, American consumers are inundated with debt; today, the average person owes more money to more people than ever

6. Id. at 291. As economist Mark Zandi notes: "Outside of employment, nothing determines the economic well-being of most American households more than a house. Most of us spend as much on our home as our incomes and wealth allow ... . Owning a home is a basic theme of nearly everyone's American dream." MARK ZANDI, FINANCIAL SHOCK: A $360^{\circ}$ LOOK AT THE SUBPRIME MORTGAGE IMPLOSION, AND How to AVOID THE NEXT FinANCIAL CRISIS 47 (2009). Significantly, in an average year "more than three-fourths of all home sales require a mortgage loan, and, on average, about three-fourths of a home's purchase price is paid for with borrowed money." Id. at 63 .

7. Lois R. Lupica, The Consumer Debt Crisis and the Reinforcement of Class Position, 40 LOY. U. CHI. L.J. 557, 603 (2009) ("Without a doubt, credit has become an essential part of the consumer economy and is relied upon by many as both a convenience and a necessity.").

8. Nicolas P. Retsinas \& Eric S. Belsky, Introduction: Borrowing to Live, in BORROWING TO Live: Consumer and Mortgage Credit Revisited 1, 3 (Nicolas P. Retsinas \& Eric S. Belsky eds., 2008). Even more broadly, one noted economist recently described "credit" as "the mother's milk of a well-functioning economy." ZANDI, supra note 6, at 28.

9. See Robert M. Lawless et al., Did Bankruptcy Reform Fail? An Empirical Study of Consumer Debtors, 82 AM. BANKR. L.J. 349, 353 (2008) ("Continuing a trend begun in the early 1980 s, the families in bankruptcy are much more deeply laden with debt. Their net worth, which has always been negative, sank further, and their debt-to-income ratios rose higher.").

10. Bill McKibben, Deep Economy: The Wealth of Communities and the Durable FUTURE 11 (2007).

11. Id.

12. Eric S. Belsky et al., Consumer and Mortgage Credit at the Crossroads, in BORRowiNG TO LIVE: CONSUMER AND MORTGAGE CREDIT REVISITED, supra note 8, at 5. 
before. $^{13}$ In 2004, 76.4\% of all households reported some form of consumer borrowing, $46.2 \%$ carried a balance on at least one credit card, $48 \%$ reported paying a mortgage loan or line of credit, 39.5\% reported making loan or lease payments on an automobile, $13.4 \%$ reported obligations on student loans, and $19.3 \%$ reported some other form of borrowing indebtedness. ${ }^{14}$ In fall of 2005 , household debt was $113 \%$ of annual income on average. ${ }^{15}$ Furthermore, according to the Federal Reserve, Americans are now carrying approximately $\$ 899.4$ billion in revolving credit debt; ${ }^{16}$ indeed, the average outstanding credit-card debt for households with a credit card was $\$ 10,679$ at the end of $2008 .{ }^{17}$ Significantly, when the current recession began in December of 2007, the longest lasting recession since World War II, ${ }^{18}$ aggregate household debt was still climbing. No doubt, the past eighteen months of national financial upheaval has only amplified the economic crisis for the average American. Consequently, many Americans are finding themselves in a "debt trap that they are having difficulty escaping." 19

Admittedly, consumers are not entirely blameless in amassing unmanageable debt obligations. $^{20}$ Granted, one way to prevent future consumer economic crises is to limit borrowing and to exercise personal

13. See William Bonner \& AdDison Wiggin, EMpire of DeBt: The Rise of AN EPIC FINANCIAL CRISIS 212 (2006); see also Lupica, supra note 7, at 557 (commenting that American consumers are indebted "to a degree never before seen in history"); Lawless et al., supra note 9, at 365 ("Today's families seeking bankruptcy relief owe more than twice as much as they did in earlier generations.").

14. Belsky et al., supra note 12 , at 5 .

15. BONNER \& WIGGIN, supra note 13, at 212.

16. Federal Reserve, Statistical Release, Consumer Credit: August 2009, http:// www.federalreserve.gov/releases/g19/20091007/g19.pdf.

17. Ben Woolsey \& Matt Schulz, Credit Card Statistics, Industry Facts, Debt Statistics, http://www.creditcards.com/credit-card-news/credit-card-industry-facts-personal-debt-statistics-127 6.php (last visited Oct. 2, 2009).

18. Associated Press, Consumers, Still Wary, Borrowed Less in May, N.Y. Times, July 9, 2009, at $\mathrm{B} 8$.

19. Belsky et al., supra note 12, at 6 .

20. Particularly with the now seemingly distant housing "boom" and the subsequent subprime mortgage meltdown, many "[h]ome buyers saw a chance to make outsized returns on homes by taking on big mortgages." ZANDI, supra note 6, at 14. But perhaps more profoundly, Professor Lois R. Lupica opines that the American consumer is not acting under "blind duress" in the incurrence of debt and the corollary acceptance of consumerism. Lupica, supra note 7, at 575. Rather, and in perfect compliance with the credit industry's intentions, Professor Lupica argues that "consumers have voluntarily adopted and realized the illusion of a middle class identity in their willingness to acquire 'stuff' at any cost." Id. As Professor Lupica further notes: "Consumers know that carrying a balance on a credit card makes all purchases more expensive and that using home equity funds to go on a Disneyland vacation can mean financing it over thirty years. Nevertheless, the acquisition yields significant benefits for consumers: an identity in addition to the 'stuff." Id. at 575-76 (footnotes omitted). 
self-restraint. ${ }^{21}$ Although it is true that Americans have been spending less and saving more to cope with the current recession, incremental savings and a newly found aversion to borrowing will not rescue the average American consumer from the noted "debt trap."

While theories explaining the expansion of consumer credit during the past decade or so abound ${ }^{22}$-all of which are certainly plausible explanations - the consumer credit market itself is primarily responsible for incentivizing increased consumerism through the liberalization of available credit. ${ }^{23}$ That is, the high debt levels for such possessions as residential homes, automobiles, and household goods for both the lower and middle classes have been prompted, and actively promoted, by the

21. This is already occurring, albeit to a limited degree. For example, from April to May of 2009 , consumer credit fell at an annual rate of $1.5 \%$. Associated Press, supra note 18 . The personal savings rate jumped to $6.9 \%$ in May of 2009, the highest since December of 1993. Id.

22. There is no dearth of commentators offering opinions as to the causes of the current financial crisis. For example, economist Mark Zandi explains the home mortgage problem:

The reality is that there is plenty of blame to go around. A financial calamity of this

magnitude could not have taken root without a great many hands tilling the soil and planting the seeds. Among the elements that fed the crisis were a rapidly evolving financial system, an eroding sense of responsibility in the lending process among both lenders and borrowers, the explosive growth of new, emerging economies amassing cash for their low-cost goods, lax oversight by policymakers skeptical of market regulation, incorrect ratings, and of course, what economists call the 'animal spirits' of investors and entrepreneurs.

ZANDI, supra note 6, at 2. Eric S. Belsky, Ren S. Essene, and Nicolas P. Retsinas describe the causes in this manner:

Expanded access to credit, particularly mortgage credit, is usually singled out as an important contributor to increasing debt-service ratios. The relaxation of constraints on maximum permissible debt-to-income ratios also figures prominently. Some argue that the rising cost of such items as housing and education has forced households to borrow more to maintain a fixed standard of living. Others blame the profligate consumer or today's consumer culture for increased consumption and debt.

Belsky et al., supra note 12, at 6-7. Professor Lois R. Lupica attributes current consumer overindebtedness to liberal credit solicitations, "confusing and exploitive lending rates and terms," inadequate underwriting standards, "shifts in consumptive norms," loss of consumer frugality, financial ignorance, and an "increasing tolerance toward debt." Lupica, supra note 7, at 560. Finally, William Bonner and Addison Wiggin offer this account for the rise in consumer indebtedness:

As the gusts of credit, debt, borrowing, and spending blew across the nation, very few of the old attitudes and institutions were left standing. Apart from Vernon Hill and a few others, lenders stopped worrying about the quality of their borrowers. Savings and loan businesses might as well have dropped the word savings from their names. And calling lenders thrifts was practically a lie; the whole industry bent to a new task - to load up consumers with as much debt as possible.

BONNER \& WIGGIN, supra note 13, at 242-43.

23. Such an indictment is certainly not new. Indeed, more than twenty years ago, Professor Charles G. Hallinan recognized that "many consumer lenders are driven by competitive necessity to 'exploit' their customers' weaknesses and incapacities through the hard selling of 'easy' credit." Charles G. Hallinan, The "Fresh Start" Policy in Consumer Bankruptcy: A Historical Inventory and an Interpretive Theory, 21 U. RICH. L. REV. 49, 67-68 (1986). 
credit industry. As Professor Lois R. Lupica tellingly describes, "[c]onsumer debt provided the fuel for the explosion of the markets for consumer goods, services, and credit. Debt became necessary to sustain the markets' very existence, and thus widespread incentives to increase consumer debt levels emerged." 24

More than a decade ago, Professor Elizabeth Warren commented on the need for consumers to have a respite from their mounting indebtedness:

Americans need a safety valve to deal with the financial consequences of the misfortunes they may encounter. They need a way to declare a halt to creditor collection actions when they have no reasonable possibility of repaying. They need the chance to remain productive members of society, not driven underground or into joblessness by unpayable debt.

With the national unemployment rate reaching $9.5 \%$ as of July of $2009,{ }^{26}$ the highest level in more than a quarter-century, ${ }^{27}$ sustained levels of unemployment are very likely to afflict American life for many months and perhaps much longer. This will effectively dump more jobless people into a weak labor market, making it harder for those already unemployed to find work, with the resulting consequences of depressed wages and reduced hours. ${ }^{28}$

The safety valve Professor Warren alluded to, and for which many Americans have turned, and will turn to, is filing for bankruptcy relief. In the past two years, the subject of bankruptcy and the economic plight of the American consumer have become part of the national consciousness. The topic has permeated discussions on economics, politics, social welfare, and business - and for good reason. Despite the enactment of the Bankruptcy Abuse Prevention and Consumer Protection Act (BAPCPA) in 2005, with one of its intended goals of reducing yearly bankruptcy filings, the number of individuals declaring bankruptcy has skyrocketed during the recession. During the twelve-month period

24. Lupica, supra note 7, at 601-02.

25. Elizabeth Warren, A Principled Approach to Consumer Bankruptcy, 71 AM. BANKR. L.J. 483, 492 (1997).

26. Peter S. Goodman, Joblessness Hits 9.5\%, Deflating Recovery Hopes, N.Y. TimES, July 3, 2009, at A1. The "underemployment rate," which "captures not only the jobless but also those working part time because their hours have been cut or they cannot find a full-time job," causes this figure to jump to $16.5 \%$. Id . at A3.

27. David Leonhardt, In Recession, a Bleaker Path for Workers to Slog, N.Y. TIMES, July 15, 2009, at A1.

28. Goodman, supra note 26 , at A3. 
ending December 31, 2008, 1,074,225 non-business bankruptcies were filed, and 714,389 Chapter 7 petitions and 358,947 Chapter 13 petitions were filed. Further, for the twelve-month period ending March 31, 2009, bankruptcy filings overall rose by $33.3 \%$ from the overall filings for the twelve-month period ending March 31, 2008. ${ }^{29}$ According to the Administrative Office of the United States Courts, the total number of bankruptcies filed during the first six months of 2009 increased by $36.5 \%$ over the same period in $2008 .^{30}$

Another avowed purpose of BAPCPA was to stop the perceived abuse of the bankruptcy system by high-income-consumer debtors who decided to shirk their financial obligations by filing for bankruptcy relief-primarily through Chapter 7-rather than repay creditors. The arguments traditionally advanced by the credit industry in seeking bankruptcy law reform, namely, that systemic abuse of the consumer bankruptcy process was occurring, have been a mythical construction of self-serving propaganda. ${ }^{31}$ And despite the reality of a bleak financial picture for millions of Americans, BAPCPA was enacted to the delight of the consumer credit industry. But, as Professor Charles Jordan Tabb aptly notes, one significant effect of BAPCPA "is to deny many consumer debtors an immediate discharge of their debts in Chapter 7 liquidation bankruptcy, leaving only the Hobson's choice of foregoing bankruptcy relief altogether or attempting to "repay their creditors the maximum that they can afford' in a Chapter 13 repayment plan," while at the same time living so close to the financial precipice that economic rehabilitation is virtually impossible to accomplish. ${ }^{32}$

Tellingly, the empirical data developed by Professor Elizabeth Warren and others over the past decade demonstrates that the consumer bankruptcy system is not rife with abuse. Rather, the consumer bankruptcy system ${ }^{33}$ is generally utilized by American families in grave

29. Press Release, U.S. Courts, Bankruptcy Filings Continue to Rise (June 8, 2009) http://www .uscourts.gov/Press_Releases/2009/BankruptcyFilingsMar2009.cfm.

30. AMERICAN BANKRUPTCY INSTITUTE ABI UPDATE: JUly 2, 2009, http://www.abiworld .org/e-news/07-02-09.html.

31. See Karen Gross, Preserving a Fresh Start for the Individual Debtor: The Case for Narrow Construction of the Consumer Credit Amendments, 135 U. PA. L. REV. 59, 88 (1986) ("Although they [(the credit industry in general)] provide no clear objective standards for finding such abuse of the bankruptcy process, the sparse 'legislative history' of the [1984] Amendments and the more prolific background surrounding prior drafts of the legislation are rife with the same subjective sense that some debtors were abusing the federal bankruptcy laws.").

32. Charles Jordan Tabb, The Death of Consumer Bankruptcy in the United States?, 18 EMORY BANKR. DEV. J. 1, 1-2 (2001) (footnotes omitted).

33. The phrase "consumer bankruptcy system" is used to denote individuals filing for bankruptcy relief under Chapter 7 of the Bankruptcy Code (straight liquidation) or Chapter 13 of the Bankruptcy Code (an adjustment or a restructuring of debt for an individual with regular income). 
financial circumstances. ${ }^{34}$ As demonstrated by the figures provided above, for today's lower-income and even middle-class families, "[m]edian family incomes have declined, basic expenses have risen, and families are shouldering unprecedented debt loads." ${ }^{35}$ Mix into this dynamic an unanticipated event such as a medical illness, job loss, or divorce, and a perfect stew for financial ruin results. Indeed, studies show that the vast majority of Chapter 7 bankruptcy filings are prompted by such life altering events as significant medical illnesses, long-term interruptions in employment, death of a spouse, or personal business failure. ${ }^{36}$ Faced with this confluence of events, resorting to the bankruptcy process is almost inevitable.

If one accepts as accurate these empirical findings regarding the characteristics of the mainstream debtor - for example, an individual or a family faced with a firestorm of financial and personal upheaval with an inability to overcome existing debt obligations - then there is apparently a vast disconnect between reality and the presumptions of Congress regarding the stereotypical, but largely non-existent, abusive debtor. Further, if the term "abuse" as seized upon by Congress in enacting the legislation, and by the credit industry during its lobbying efforts leading

34. Warren, supra note 25 , at 493 . As a recent empirical article on bankruptcy law conducted by a gathering of academics from different disciplines concludes, individuals and families currently filing for bankruptcy relief are in historically worse financial despair than in previous decades, as median net worth continues to plummet while total debt loads grow exponentially. See Lawless et al., supra note 9, at 373 (explaining that families currently filing for bankruptcy protection "are in worse shape than those filing in earlier years" due to an increase in total debts and a decrease in net worth).

35. Lawless et al., supra note 9, at 349-50 (footnotes omitted).

36. In an empirical study conducted by Professor Warren, "more than eight out of ten families with children" identify just three reasons for their bankruptcy filings: "job loss, family breakup, and medical problems." See Elizabeth Warren, The Growing Threat to Middle Class Families, 69 BROOK. L. REV. 401, 411 (2004) [hereinafter Warren, The Growing Threat]. For other scholarly literature on the causes of consumer bankruptcy filings, see also TERESA A. SULLIVAN ET AL., THE Fragile Middle Class: AMERICANS IN DEBT 2 (2000) (noting that financial stress leading to bankruptcy comes from five sources, including "volatility of jobs," "divorce and changing parenting patterns," and "medical problems"); EliZABETH WARREN \& AMELIA WARREN TYAGI, THE TwOInCOME TRAP: Why Middle-Class Mothers and FATHERS ARE GOING BROKE 7-8 (explaining why two-income families are no longer financially prepared for unseen dangers, such as a child getting sick, a father losing a job, or a divorce); Lawless, et al., supra note 9, at 379 (explaining that one model of consumer bankruptcy argues that "[f]amilies are driven to bankruptcy when they suffer serious economic dislocations, such as job loss, medical problems or family breakups"); Tabb, supra note 32, at 14 (stating that "[s]tudies show that the vast majority of Chapter 7 bankruptcies are caused by medical problems, divorce, or job layoffs"); Elizabeth Warren, The Bankruptcy Crisis, 73 IND. L.J. 1079, 1100 (1998) [hereinafter Warren, The Bankruptcy Crisis] (stating that whether through layoffs, medical debt, divorces, or other problems, "[e]very personal bankruptcy filing represents a family crisis"); Elizabeth Warren, Financial Collapse and Class Status: Who Goes Bankrupt?, 41 OsGoOdE HALl L.J. 115, 145 (2003) [hereinafter Warren, Financial Collapse and Class Status] (explaining that job difficulties, medical debt, and divorce may "figure importantly in [a family's] financial demise"). 
to the enactment of BAPCPA, means incurring debt with a subsequent inability to repay and consequently choosing to file for bankruptcy relief, then the meaning of "abuse" would be wholly inconsistent with traditional bankruptcy philosophy. ${ }^{37}$ All of this leads to a single observation; namely, the time is perfectly ripe for Congress, the courts, the academic community, and other participants in the consumer bankruptcy system to reevaluate the policies, goals, and purposes of the bankruptcy laws.

This devolves into an obvious inquiry: where should one start in the reexamination process? The only reasonable place to begin is the consumer-bankruptcy discharge. As will be discussed more fully below, in the past, bankruptcy law scholars have advanced an assortment of theories for explicating the consumer-bankruptcy discharge. To be sure, these theories are all plausible explanations and certainly attractive, and the purpose of this contribution is not to dissect or critique these existing theories. Nevertheless, one way in which all of the previous theories arguably fall short is that they prove to be too restrictive to account for, and rectify, all of the issues facing the individual debtor.

Therefore, what this Article attempts to do is propose a general overarching philosophical theory, a "metatheory," which is then applied to a particular, concrete problem. ${ }^{38}$ Accordingly, this Article advances a metatheory for the consumer-bankruptcy discharge predicated upon classical utilitarianism. Whether one agrees with utilitarianism as an appropriate theory of justice and morality, it is undeniably a powerful concept - one that has engendered much discussion in the scholarly literature of the disciplines of philosophy, law, and economics. ${ }^{39}$ To be

37. See Gross, supra note 31, at 150 (making a similar point but in the context of interpreting certain amendments to the Bankruptcy Code promulgated by Congress in 1984)

38. Professor Karen Gross recognized such an approach. See Karen Gross, Failure AND FORGIVENESS: REBALANCING THE BANKRUPTCY SYSTEM 15 (1997).

39. See generally Richard B. BRANDT, Morality, Utilitarianism, AND Rights (1992) (discussing utilitarianism in the context of normative ethics, moral rights, and public policy); D. H. Hodgson, Consequences of Utilitarianism: A Study in Normative Ethics and Legal THEORY (1967) (arguing against "certain forms of utilitarianism" because of the consequences of using utilitarian principles); P. J. Kelly, Utilitarianism AND Distributive JustiCE: JeReMY BENTHAM AND THE CIVIL LAW (1990) (discussing criticisms of Jeremy Bentham's theory of distributive justice); DAVID LYONS, IN THE INTEREST OF THE GOVERNED: A STUDY IN BENTHAM'S PHILOSOPHY OF UTILITY AND LAW (1973) (exploring Jeremy Bentham's utilitarianism and his theory of law); RICHARD A. POSNER, Frontiers OF LEGAL THEORY (2001) (discussing the use of utilitarianism in economics); JOHN RAWLS, A THEORY OF JUSTICE (1971) (comparing classical utilitarian concepts of justice with "justice as fairness"); J. J. C. SMART \& BERNARD WILLIAMS, UTILITARIANISM FOR AND AGAINST (1973) (presenting a system of utilitarian ethics called "actutilitarianism"); Peter Unger, Living High AND LetTing Die: OUR Illusion OF INNOCENCE (1996) (describing unusual moral judgments and stating that, at times, utilitarian philosophy might explain it); UTILITY AND RighTS (R. G. Frey ed., 1984) (exploring unconstrained utilitarianism and 
sure, adopting a utilitarian approach reflects a particular normative selection among competing values and alternative possibilities. ${ }^{40}$

Nevertheless, utilitarian positions have been adopted for many divergent purposes. However, two overriding lines of thought can be identified. One line of thought urges the merits of utilitarianism as a "general moral philosophy," while the other adopts utilitarianism as proposing a principle that is especially appropriate to the decisions of public bodies, such as legislatures and courts, "even if [this utilization of the principle] does not form the ultimate basis of morality in general.",41 This Article is concerned with the latter approach; that is, to propose an operative metatheory of the consumer-bankruptcy discharge- one that can be adopted by the bankruptcy courts in construing relevant provisions of the Bankruptcy Code or by Congress if it ever seriously reexamines the efficacy of and assumptions underlying BAPCPA. Admittedly, one limitation of this Article is its failure to develop solutions to all possible issues in advocating a theory of discharge based on utilitarianism. That said, however, the primary goals are both narrow and broad at the same time; narrowly, to serve as a corrective response to the congressional enactment of BAPCPA and the current economic crisis plaguing the nation, and broadly, to advance the debate on consumer bankruptcy theory and policy.

Part II of this Article discusses the parameters and scope of the bankruptcy discharge. Part III addresses the efforts by the consumercredit industry to have the bankruptcy laws reformed. Part IV discusses several features of BAPCPA that hinder a debtor's ability to obtain a complete fresh start. Part V discusses the existing scholarly literature and theories of the consumer-bankruptcy discharge. Part VI discusses classical-utilitarian philosophy and then proposes a contemporary "consumer utility" theory of the bankruptcy discharge that is derivative of those utilitarian principles. Part VII then applies this theory of discharge to the consumer-bankruptcy dynamic, and offers certain reform proposals for Congress and the courts. Part VIII raises and discusses potential objections to the consumer-utility theory advanced herein. Finally, Part IX offers a brief conclusion.

the rights-theory); RAYMOND WACKS, UNDERSTANDING JURISPRUDENCE: AN INTRODUCTION TO LEGAL THEORY (2005) (discussing utilitarianism as it relates to theories of justice and theories of rights).

40. See Ronald A. Cass, Coping with Life, Law, and Markets: A Comment on Posner and the Law-and-Economics Debate, 67 B.U. L. REv. 73, 89-91 (1987) (recognizing this potential limitation in the context of parental adoptions).

41. N.E. Simmonds, Central Issues in Jurisprudence: Justice, LaW and Rights 19 (1986). 


\section{The NATURE, Purpose, AND SCOPE OF THE CONSUMER DischarGe}

To be sure, one of the central, if not the most significant, policies underlying consumer bankruptcy law is the notion of the "discharge" of one's indebtedness. ${ }^{42}$ The legal effect of a bankruptcy discharge is relatively straightforward with respect to individual debtors. The entry of a discharge "operates to release an individual debtor's in personam obligation to pay prepetition indebtedness and serves as a permanent injunction against any act to collect a discharged debt." 43 This freedom from personal liability for pre-petition debt is known as the proverbial "fresh start." 44 In other words, the discharge of debts, particularly in a Chapter 7 liquidation proceeding, represents a trade-off: a financially struggling debtor is generally relieved of his or her pre-petition

42. See Nancy C. Dreher \& Matthew E. Roy, Bankruptcy Fraud and Nondischargeability Under Section 523 of the Bankruptcy Code, 69 N.D. L. REV. 57, 57 (1993) ("The most sweeping remedy available to a debtor in bankruptcy is the discharge of the debtor's personal liability to his or her creditors."); Theodore Eisenberg, Bankruptcy Law in Perspective, 28 UCLA L. REV. 953, 977 (1981) (recognizing that the notion of a discharge "dominates consumer bankruptcy law"); Richard E. Flint, Bankruptcy Policy: Toward a Moral Justification for Financial Rehabilitation of the Consumer Debtor, 48 WASH. \& LEE L. REV. 515, 515 (1991) ("The essence of our consumer bankruptcy law is the discharge." (footnote omitted)); Nicholas L. Georgakopoulos, Bankruptcy Law for Productivity, 37 WAKE FOREST L. REV. 51, 55 (2002) (noting that the discharge and "fresh start" is a major breakthrough of contemporary bankruptcy law); Garrard Glenn, Essentials of Bankruptcy: Prevention of Fraud, and Control of Debtor, 23 VA. L. REV. 373, 380 (1937) (noting that the "privilege" of a discharge of one's debts was "one of the greatest of liberal reforms" of bankruptcy law); Margaret Howard, A Theory of Discharge in Consumer Bankruptcy, 48 OHIO ST. L.J. 1047, 1047 (1987) ("That we should have some system of discharge in bankruptcy is a settled question."); Thomas H. Jackson, The Fresh-Start Policy in Bankruptcy Law, 98 HARV. L. REV. 1393, 1393 (1985) ("Discharge, the doctrine that frees the debtor's future income from the chains of previous debts, lies at the heart of bankruptcy policy."); Philip Shuchman, An Attempt at a "Philosophy of Bankruptcy", 21 UCLA L. REV. 403, 420-21 (1973) ("The most significant aspect of [debtors'] bankruptcies is the granting of the discharge, which serves as a legally effective bar to further collection efforts by most creditors."); Warren, supra note 25, at 483 (noting that the bankruptcy discharge, and its accompanying "fresh start," is a "star[] of consumer bankruptcy").

43. George H. Singer, Section 523 of the Bankruptcy Code: The Fundamentals of Nondischargeability in Consumer Bankruptcy, 71 AM. BANKR. L.J. 325, 325; see also Johnson v. Home State Bank, 501 U.S. 78, 84 (1991) (noting that a "bankruptcy discharge extinguishes only one mode of enforcing a claim - namely, an action against the debtor in personam - while leaving intact another-namely, an action against the debtor in rem."); In re Hawkins, 377 B.R. 761, 766 (Bankr. S.D. Fla. 2007) (“A Chapter 7 discharge, 11 U.S.C. § 727, voids all of the debtor's personal liability on a debt.").

44. See Jay L. Zagorsky \& Lois R. Lupica, A Study of Consumers' Post-Discharge Finances: Struggle, Stasis, or Fresh-Start?, 16 AM. BANKR. INST. L. REV. 283, 283 (2008) ("Bankruptcy's central theoretical objective, from the perspective of the individual debtor, is to afford debtors the opportunity for a 'fresh start."'); see also Rafael Efrat, The Moral Appeal of Personal Bankruptcy, 20 WhitTIER L. REV. 141, 141 (1999) ("The fresh start principle generally takes the form of forgiving the debtor part or all of the debts she incurred prior to her bankruptcy filing."); Katherine Porter \& Deborah Thorne, The Failure of Bankruptcy's Fresh Start, 92 CORNELl L. REV. 67, 68 (2006) ("The principal theory of consumer bankruptcy in America is that it provides a 'fresh start' to debtors."). 
indebtedness by being granted a discharge, and in return, the debtor is required to surrender certain assets to the bankruptcy court and bankruptcy trustee. Although the concept of a discharge of one's indebtedness first appeared in England in 1705 in the Statute of 4 Anne, ${ }^{45}$ the modern discharge in American bankruptcy law did not appear until 1898.

A codified bankruptcy law has been a part of Anglo-American jurisprudence for approximately half a millennium. ${ }^{46}$ The provision of a federal-bankruptcy-law-system is provided for in the United States Constitution itself. Article I, Section 8, Clause 4 of the Constitution provides that "Congress shall have Power... [t]o establish an uniform Rule of Naturalization, and uniform Laws on the subject of Bankruptcies throughout the United States . . .."47

The first United States bankruptcy law was passed in 1800 , but remained in existence for only three years. ${ }^{48}$ Under the Bankruptcy Act of 1800 , the discharge was available only to merchants forced into bankruptcy involuntarily, and who ended up cooperating with creditors in the bankruptcy proceeding by turning over non-exempt assets. ${ }^{49}$ Furthermore, before a discharge could be granted, the bankruptcy "commissioners" of the time "had to certify to the federal district judge that the debtor had cooperated, and two-thirds of the creditors, by number and by value of claims, had to consent to the discharge." ${ }^{50}$

Congress enacted the next federal-bankruptcy law in 1841, and it lasted for only two years. ${ }^{51}$ As Professor Charles Jordan Tabb describes, the Bankruptcy Act of 1841 represented a "watershed event in bankruptcy history" for two principal reasons. ${ }^{52}$ First, filing for bankruptcy could now be accomplished voluntarily by the debtor, as opposed to solely involuntarily by a contingency of creditors. ${ }^{53}$ Second,

\footnotetext{
45. An Act to Prevent Frauds Frequently Committed by Bankrupts, 1705, 4 Ann., c. 17, § 17 (Eng.).

46. Charles Jordan Tabb, The Historical Evolution of the Bankruptcy Discharge, 65 AM. BANKR. L.J. 325, 325 (1991).

47. U.S. CONST. art. I, $\S 8$, cl. 4.

48. Bankruptcy Act of 1800, ch. 19, 2 Stat. 19, repealed by Act of Dec. 19, 1803, ch. 6, 2 Stat. 248 (1803).

49. Charles Jordan Tabb, The Scope of the Fresh Start in Bankruptcy: Collateral Conversions and the Dischargeability Debate, 59 GEO. WASH. L. REV. 56, 63 (1990).

50. Charles Jordan Tabb, The History of the Bankruptcy Laws in the United States, 3 AM. BANKR. INST. L. REV. 5, 15 (1995).

51. Bankruptcy Act of 1841, ch. 9, 5 Stat. 440, repealed by Act of Mar. 3, 1843, ch. 82, 5 Stat. 614.

52. Tabb, supra note 50 , at 17.

53. Id.
} 
the bankruptcy process was opened to "all persons," and not strictly limited to the class of merchants or traders under prior law. ${ }^{54}$ Moreover, the promulgation of the Bankruptcy Act of 1841 aided in the availability of debtors actually receiving a discharge of their debts; that is, a debtor would receive a discharge of debt unless a majority of creditors in number and amount of indebtedness took affirmative action to contest the discharge. ${ }^{55}$

Quite significantly, in the legislative debates preceding the enactment of the Bankruptcy Act of 1841, Whig party leader Henry Clay made remarks reflective of a philosophy that the bankruptcy laws should serve a purpose greater than simply relieving the immediate debtor from his or her debts. Senator Clay commented:

The right of the State (I use the term in its broadest sense), to the use of the unimpaired faculties of its citizens as producers, as consumers, and as defenders of the commonwealth, is paramount to any rights or relations which can be created between citizen and citizen. But an honest and unfortunate debtor, borne down by a hopeless mass of debt from beneath which he can never rise, is prostrated and paralyzed, and rendered utterly incapable of performing his duties to his family or his country. To say nothing of the dictates of humanity ... I maintain that the public right of the State, in all the faculties of its members, moral and physical, is paramount to any supposed rights which appertain to a private creditor. This is the great principle which lies at the bottom of all bankrupt laws, and it is this which gives to the States the right to demand the passage, and imposes upon congress the duty of enacting a bankrupt system.

The next federal-bankruptcy law, the Bankruptcy Act of 1867, lasted until 1878. ${ }^{57}$ The subsequent Bankruptcy Act of 1898 represented the beginning of permanent federal-bankruptcy legislation. ${ }^{58}$ The view of a national-bankruptcy law serving as social legislation for the public good was carried forward to the debates leading up to the enactment of the Bankruptcy Act of $1898 .{ }^{59}$ For example, in the opening debate on the

54. Id.

55. Vern Countryman, A History of American Bankruptcy Law, 81 CoM. L.J. 226, 229 (1976); see also Tabb, supra note 50, at 17 ("Creditors could ... block the discharge, but only through a written dissent filed by a majority in number and value of creditors.").

56. John M. Czarnetzky, The Individual and Failure: A Theory of the Bankruptcy Discharge, 32 ARIZ. ST. L.J. 393, 428 (2000) (quoting CONG. GloBe, 26th Cong., 1st Sess. 816 (1840) (emphasis added)).

57. Bankruptcy Act of 1867, ch. 176, 14 Stat. 517, repealed by Act of June 7, 1878, ch. 160, 20 Stat. 99.

58. Bankruptcy Act of 1898, ch. 541, 30 Stat. 544 (1898) (repealed 1978).

59. For example, in 1883 the United States Supreme Court commented as follows with respect 
bankruptcy bill, Senator Lindsay provided the following justification for the consumer discharge in pertinent part as follows:

The fact is that a discharge can be justified only upon the grounds of sound public policy; that is, the State is more interested in having an honest debtor relieved from obligations he can not meet, and given an opportunity to better support and educate his family and accumulate property upon which to pay taxes, than in having him held in financial bondage forever by individual creditors. The binding obligation of a contract ought not to be annulled except on this ground.... The true doctrine is that no dishonest debtor should receive a discharge, no matter what percentage his estate pays or what number of his creditors have been induced to assent; but, on the other hand, every honest debtor should be discharged, irrespective of the money value of his estate or the assent of his creditors. ${ }^{6}$

As Professor Tabb has observed, the Bankruptcy Act of 1898 marked "the arrival of the 'modern' American pro-debtor discharge policy.",61 This feat was accomplished in two specific ways. In contrast to historical precedent, the Bankruptcy Act of 1898 wrested control of the discharge from the court and at the same time eliminated the need for creditor consent or a minimum dividend as a prerequisite for a debtor to obtain a discharge. $^{62}$ Aptly, and as Professor Tabb noted, "[T] that the debtor's entitlement to a discharge rests solely on the impact on

to the national bankruptcy laws:

The constitution expressly empowers the congress of the United States to establish such laws. Every member of a political community must necessarily part with some of the rights which, as an individual, not affected by his relation to others, he might have retained. Such concessions make up the consideration he gives for the obligation of the body politic to protect him in life, liberty, and property. Bankrupt laws, whatever may be the form they assume, are of that character.

Canada S. Ry. v. Gebhard, 109 U.S. 527, 536 (1883).

60. Czarnetzky, supra note 56, at 429-30 (quoting 30 CONG. REC. 603 (1897) (emphasis added)). Early commentators on the Bankruptcy Act of 1898 echoed this sentiment of bankruptcy law as social legislation. As F. Regis Noel argued in 1919:

Higher civilization demands for the individual civil liberty and equal opportunity; society needs the untrammeled effort of every honest man. A practical system for the relief of bankrupts, because of the conflicting character of the ends to be accomplished, must inevitably complicate the task of the State. Such system should be an harmonious combination of the maxims of the law, the rules of ethics and the principles of social economics. It should be the result of the legal rights between man and man as tempered by Christian principles and the prerogative of society to receive the benefits of the labor of every member. The laws of bankruptcy are not designed solely for the interest of the debtor or of the creditor or indeed for their combined interest. The claim of justice and the commercial development of the nation also must be considered.

F. REGIS NOEL, A HiSTORY OF THE BANKRUPTCY LAW 181 (1919) (emphasis added).

61. Tabb, supra note 46 , at 364 .

62. Id. 
the interests of the immediately affected creditors was rejected in 1898." $"$ As a direct result of the Bankruptcy Act of 1898, the discharge was no longer viewed as an inducement to debtors to cooperate in the bankruptcy proceeding; instead the 1898 Act "recognized formally for the first time the overriding public interest in granting a discharge to 'honest but unfortunate' debtors." 64

The Bankruptcy Act of 1898 was repealed in 1978 and replaced by the Bankruptcy Reform Act of 1978, now known as the modern "Bankruptcy Code ("the Code")." 65 Significant to this evolution of the bankruptcy laws is Professor John M. Czarnetzky's observation that "reform debates concerning the bankruptcy discharge since the 1898 Act have centered not around its basic utility, but rather over how it should be limited." based upon current economic conditions and Congress's foolhardy enactment of BAPCPA, Congress, the courts, and commentators of bankruptcy law must once again embrace the notion of the bankruptcy laws as social legislation rather than as a mechanism to clamp down on the efficacy of the consumer discharge, thereby perpetuating a debtor's servitude to his or her creditors.

The social utility of providing individual debtors with a fresh start is deeply rooted in American bankruptcy law. ${ }^{67}$ In perhaps the most cited recitation of the fresh start principle, the Supreme Court of the United States stated as follows in Local Loan Co. v. Hunt:

One of the primary purposes of the Bankruptcy Act is to "relieve the honest debtor from the weight of oppressive indebtedness, and permit him to start afresh free from the obligations and responsibilities consequent upon business misfortunes." This purpose of the act has been again and again emphasized by the courts as being of public as well as private interest, in that it gives to the honest but unfortunate debtor who surrenders for distribution the property which he owns at the time of bankruptcy, a new opportunity in life and a clear field for future effort, unhampered by the pressure and discouragement of preexisting debt. ${ }^{68}$

\footnotetext{
63. Id.

64. Id.

65. Pub. L. No. 95-598, 92 Stat. 2549 (1978).

66. Czarnetzky, supra note 56, at 431.

67. So too in English bankruptcy law, upon which American bankruptcy law is predicated. As early as 1765 William Blackstone commented that by virtue of a discharge "the bankrupt becomes a clear man again; and, by the assistance of his allowance and his own industry, may become a u[s]eful member of the commonwealth." 2 WiLliam BLACKSTONE, COMMENTARIES $* 484$.
}

68. Local Loan Co. v. Hunt, 292 U.S. 234, 244 (1934) (citations omitted); see also U.S. Dep't 
The linchpin of the consumer discharge is that the debtor must demonstrate forthrightness and honesty throughout the bankruptcy proceeding, including in the disclosures and financial information provided on the bankruptcy petition and accompanying schedules. ${ }^{69}$ The idea that bankruptcy should be a respite for only the honest debtor has existed since the early nineteenth century. "As early as 1817 , Congress was petitioned to pass a bankruptcy statute that would 'shelter the honest and unfortunate debtor.",70 By extrapolation, then, the granting of the discharge is not an absolute right, but is dependent upon the ingenuous dealings of the debtor. ${ }^{71}$ Indeed, one bankruptcy court noted that "“[a]ccuracy, honesty, and full disclosure are critical to the functioning of bankruptcy,' and are 'inherent in the bargain for the discharge.", 72 To this end, unless the individual debtor violates a proscribed form of behavior contained within the Code or developed through federalbankruptcy law, an individual who files for bankruptcy relief can ordinarily obtain a discharge from the majority of his or her pre-petition debts in exchange for surrendering any non-exempt assets. ${ }^{73}$

More precisely, there are two components to the consumer discharge, namely, an affirmative "global" discharge of all pre-petition indebtedness and an exception from the "global" discharge for certain types of debts that Congress has deemed inappropriate for debtorforgiveness. In a Chapter 7 liquidation proceeding, the "global" discharge is provided by $\S 727$ of the Code, which provides that a court "shall grant the debtor a discharge, unless" the debtor violates some form

of Health \& Human Servs. v. Smith, 807 F.2d 122, 123 (8th Cir. 1986) ("The bankruptcy laws embody a congressional policy to free an honest debtor from his financial burdens and thus allow him to make an unencumbered fresh start." (citing Kokoszka v. Belford, 417 U.S. 642, 645-46 (1974))).

69. See In re Slentz, 157 B.R. 418, 420 (Bankr. N.D. Ind. 1993) ("Since the proper operation of the bankruptcy system depends, to a large extent, upon debtors honestly and forthrightly completing the schedules and statements which are filed with the court, attempts at cheating cannot be made to appear too attractive.").

70. Howard, supra note 42, at 1050 (citing 2 AMERICAN STATE PAPERS: Miscellaneous 415 (Walter Lowrie \& Walter S. Franklin eds., Washington, Gales \& Seaton 1834)). As Professor Margaret Howard notes, "[t]hroughout the nineteenth century, petitions asking Congress to pass a bankruptcy law and the legislative histories of the various statutes passed reveal a concern that discharge be available only for honest debtors." Id.

71. See In re Williams, 286 F. 135, 137 (W.D.S.C. 1921) ("The granting of a discharge is not an absolute right, existing at the time of the filing of a petition in bankruptcy. It is dependent upon the square dealings and honest purpose of the bankrupt as evidenced by his acts and doings after the filing of his petition.").

72. In re Kestell, 99 F.3d 146, 149 (4th Cir. 1996) (quoting the lower court).

73. See Jackson, supra note 42, at 1393. 
of proscribed behavior, mostly attributable to the lack of candor or outright disobedience by the debtor. ${ }^{74}$

The types of prohibited conduct that would lead to a denial of the discharge pursuant to $\S 727$ of the Code relate to either the debtor's behavior leading up to the bankruptcy filing or his or her conduct during the bankruptcy proceeding itself. For example, a court may deny a debtor's discharge if he or she: (i) transferred or destroyed property within one year before the filing date "with the intent to hinder, delay, or defraud a creditor"; 75 (ii) transferred or destroyed "property of the estate" after the bankruptcy petition is filed; ${ }^{76}$ (iii) "concealed, destroyed, mutilated, falsified, or failed to keep or preserve" any financial documents; ${ }^{77}$ (iv) made a false oath or presented a false claim in connection with the bankruptcy case; ${ }^{78}$ or (v) failed "to obey any lawful order of the court other than an order to respond to a material question or to testify." 79 Quite significantly, then, a debtor who either transgresses a prohibited behavioral norm, fails to perform his or her duties in the bankruptcy case, or abuses the bankruptcy process itself will be denied any discharge of pre-petition debts under $\S 727$ of the Code. ${ }^{80}$

Even if the individual debtor conforms to the appropriate standard of behavior so as to receive his or her "global" discharge under $\S 727$ of the Code, it is still quite possible for a specific debt to be excepted from the discharge by operation of $\S 523 .{ }^{81}$ Section 523 provides for nineteen categories of debts to be excepted from discharge; ${ }^{82}$ the types of debts excepted from discharge constitute a congressional determination that a creditor's interest in recovering full payment of a debt within the categories of debts specified in $\S$ 523(a) “outweigh[s] the debtor's interest in a complete fresh start." ${ }^{, 83}$ Of principal importance for the consumer debtor, some of the debts excepted from discharge under $\S$ 523(a) include income taxes, credit card debt, student loans, and

74. See 11 U.S.C. $§ 727(a)$ (2006). The "global" discharge in a Chapter 13 individual rehabilitation bankruptcy case is much broader in scope. See $\S 1328($ a).

75. $\S 727(\mathrm{a})(2)(\mathrm{A})$.

76. $\$ 727(\mathrm{a})(2)(\mathrm{B})$.

77. $\S 727(\mathrm{a})(3)$.

78. $\$ 727(\mathrm{a})(4)$

79. $§ 727(\mathrm{a})(6)(\mathrm{A})$.

80. Royal Am. Oil \& Gas Co. v. Szafranski (In re Szafranski), 147 B.R. 976, 981 (Bankr. N.D. Okla. 1992).

81. See $\S 523($ a) (listing types of debt not discharged even with a discharge under $\S 727$ ).

82. Id.

83. Alibatya v. New York Univ. (In re Alibatya), 178 B.R. 335, 337 (Bankr. E.D.N.Y. 1995) (citing Grogan v. Garner, 498 U.S. 279, 287 (1991)). 
financial obligations arising from a domestic support obligation or marital separation agreement. ${ }^{84}$

The interrelated remedies of the consumer discharge, namely, the denial of the "global" discharge and the specific exceptions to the "global" discharge under $\S 523$, serve the bankruptcy-law policy of affording a fresh start "only to the honest but unfortunate debtor." 85 Finally, the notion of the fresh start is effectuated by $\S 524$ of the Code, ${ }^{86}$ which provides an injunction against any effort to collect a discharged debt as a personal liability of the debtor. ${ }^{87}$

Although the enactment of the Code in 1978 was initially viewed as a victory for debtors, over the past thirty years, the notion of bankruptcy law has radically changed. Instead of a law affording financially struggling debtors with an opportunity for a second financial life, bankruptcy law became viewed as an evil sword rather than a much needed shield - a law that enabled debtors to cavalierly shed their debts without any moral compunction regarding honoring their contractual obligations, the subject matter to which this Article now turns.

\section{THE CREDIT INDUSTRY's REBELLION AGAINST THE BANKRUPTCY STATUS QUO}

The enactment of the modern Bankruptcy Code in 1978 was a watershed event, particularly because it was the first promulgation of a federal bankruptcy law that did not directly respond to an economic depression. ${ }^{88}$ More significantly, though, the 1978 Bankruptcy Code was viewed by many as favoring consumer debtors to the detriment of their creditors, in part because the Code increased exemption levels and

84. See 11 U.S.C. § 523(a)(1), (2), (5), (8), (15) (2006). In order to have a particular debt excepted from discharge, it is incumbent upon the complaining creditor to initiate an adversary proceeding against the debtor, which results in a separate legal proceeding in the bankruptcy court. See FED. R. BANKR. P. 7001(6). The burden of establishing the non-dischargeability of a debt is upon the creditor objecting to the discharge. See FED. R. BANKR. P. 4005. By operation of $\S 523$, "any debt not excepted by Congress in the Bankruptcy Code is presumed to be dischargeable." Kessler v. Butler (In re Butler), 186 B.R. 371, 372 (Bankr. D. Vt. 1995).

85. Szafranski, 147 B.R. at 981.

86. See generally 11 U.S.C. $\$ 524$ (2006).

87. See Jarrett v. Dep't of Taxation (In re Jarrett), 293 B.R. 127, 131 (Bankr. N.D. Ohio 2002) ("The purpose of the discharge injunction of $\S 524$ is to promote the fresh start policy of the Bankruptcy Code by protecting a debtor against actions brought on prepetition debts."); see also Gross, supra note 31, at 62 ("An individual debtor's statutory ability to obtain a fresh start has its primary locus in the discharge and exemption provisions of the Bankruptcy Code.").

88. Tabb, supra note 50, at 32. See also Flint, supra note 42, at 551 ("The [Bankruptcy] Code was the first bankruptcy law passed without the direct intervention of a financial disaster."). 
broadened the categories of debts that could be discharged. ${ }^{89}$ Of marked significance to this Article is Professor Richard Flint's historical observation that the enactment of the Code in 1978 signified the continuing trend of 178 years of bankruptcy legislation evolving from a process of attempting to achieve singularly a greater return for creditors to one of "concern for the wellbeing of the financially downtrodden."

Following the 1978 enactment of the Code, the number of individuals filing for personal bankruptcy increased dramatically. ${ }^{91}$ In the six years following the enactment of the Code, the number of bankruptcy filings increased more than any other time in history. ${ }^{92}$ In

89. See, e.g., Hallinan, supra note 23, at 52 ("In the context of consumer bankruptcies, the Code is most notable for its significant expansion of the protection afforded to bankrupt debtors."); Tabb, supra note 50, at 36 ("Discharge was made readily available save but for a number of excepted debts."); Michelle J. White, Personal Bankruptcy Under the 1978 Bankruptcy Code: An Economic Analysis, 63 IND. L.J. 1, 2 (1987) ("The 'fresh start' consideration appears to have been paramount when Congress revised personal bankruptcy procedures under the Bankruptcy Reform Act of 1978, commonly referred to as the new Bankruptcy Code. The Code raised the exemption level applicable in personal bankruptcy cases and widened the types of debt which could be discharged." (footnote omitted)). As noted by Professor Karen Gross:

At the heart of the [congressional reform] effort [which began in 1968] was a congressional bias in favor of preserving and promoting the rights of individual debtors and encouraging them to utilize the federal bankruptcy system to achieve a fresh start. The resulting legislation - the Bankruptcy Reform Act of 1978-substantially simplified the procedures for individual debtor recourse to bankruptcy relief and, despite the consumer credit industry's considerable opposition, expanded the rights of and protections accorded to individual debtors under the federal bankruptcy laws.

Gross, supra note 31, at 75-76 (footnote omitted).

90. Flint, supra note 42, at 552. In support of his own thesis of a natural law theory of morality justifying the consumer discharge, Professor Flint observes as follows:

The historical treatment of debtors in the United States also reflects a rich heritage of growth in the area of social justice. Thus, the underlying goal of the consumer bankruptcy process has evolved from retaliation, to compensation, and now to compassion and concern for those less fortunate in our society. Through this evolution the fundamental values of dignity, humanitarianism, and fairness have become more firmly entrenched.

Id. at 554 .

91. A great deal of research, employing both legal and social science methodologies, has been conducted in an attempt to explain the significant spike in consumer bankruptcy filings following the enactment of the Bankruptcy Code in 1978. See generally Jagdeep S. Bhandari \& Lawrence A. Weiss, The Increasing Bankruptcy Filing Rate: A Historical Analysis, 67 AM. BANKR. L.J. 1 (1993); William J. Boyes \& Roger L. Faith, Some Effects of the Bankruptcy Reform Act of 1978, 29 J.L. \& ECON. 139 (1986); F.H. Buckley \& Margaret F. Brinig, The Bankruptcy Puzzle, 27 J. LEGAL STUD. 187 (1998); Ian Domowitz \& Thomas L. Eovaldi, The Impact of the Bankruptcy Reform Act of 1978 on Consumer Bankruptcy, 36 J.L. \& ECON. 803 (1993); Ian Domowitz \& Robert L. Sartain, Incentives and Bankruptcy Chapter Choice: Evidence from the Reform Act of 1978, 28 J. LEGAL StUd. 461 (1999); Michelle J. White, Why It Pays to File for Bankruptcy: A Critical Look at the Incentives Under U.S. Personal Bankruptcy Law and a Proposal for Change, 65 U. CHI. L. REV. 685 (1998).

92. Domowitz \& Eovaldi, supra note 91, at 804. "The number of nonbusiness cases filed in the twelve-month period ending June 30, 1980, was 277,884. For the years ending June 30, 1981, 
1983, 286,000 consumer-bankruptcy cases were filed; by 2003, this figure approximated 1.6 million consumer-bankruptcy cases per year, an increase of $560 \%$ in a twenty-year period. ${ }^{93}$

As the number of personal-bankruptcy filings rose during the $1980 \mathrm{~s}$ and 1990s, an incredibly loud alarm rang through the commerciallending and credit industries. As Professor Charles G. Hallinan observed, with the increased consumer-bankruptcy filings following the enactment of the Code "was a spreading concern (or at least suspicion) that some significant portion of consumers resorting to bankruptcy might be doing so in the absence of 'real need,' obtaining a discharge notwithstanding a capacity to repay and an absence of financial distress." 94 As a result of this "concern," a movement for the reexamination of the efficacy of the existing bankruptcy laws surfaced. ${ }^{95}$ Given the opportunity, creditor interest groups circled their proverbial wagons and lobbied Congress intensely for a "crackdown" on the dynamics of consumer bankruptcy. ${ }^{96}$

One of the major proponents for bankruptcy-reform legislation was the Bankruptcy Issues Council, which consisted of major credit-card companies and financial institutions that issued credit cards to consumers. $^{97}$ Another creditor interest group that lobbied heavily for bankruptcy reform was the National Consumer Bankruptcy Coalition, which consisted of such institutions as MasterCard, Visa, and the American Bankers Association. ${ }^{98}$ Viewing the rise in consumer

through June 30, 1984, the number of cases filed were 313,499; 311,690; 305,082; and 282,151. The previous record number of cases in a year was 254,484 in 1975." Id. at n.4.

93. Jean Braucher, Consumer Bankruptcy as Part of the Social Safety Net: Fresh Start or Treadmill?, 44 SANTA ClARA L. REV. 1065, 1071 (2004).

94. Hallinan, supra note 23 , at 89 .

95. The re-examination of the Code was largely engendered by the increase in bankruptcy filings during the 1980s and 1990s. From 1978 to 1998 , yearly bankruptcy filings rose from 200,000 to 1.4 million. Robert J. Landry, III, The Policy and Forces Behind Consumer Bankruptcy Reform: A Classic Battle Over Problem Definition, 33 U. MEM. L. REV. 509, 514 (2003). The increased trend of consumers filing for bankruptcy protection "ignited a debate among pro-debtor and procreditor groups about whether the Bankruptcy Code need[ed] to be reformed." Id. at 515.

96. See id. at 516 ("The great surge of bankruptcies in the 1990s provided the credit industry with ammunition to seek bankruptcy reform that would make it more difficult for people to avoid paying their debts. The surge in bankruptcy cases is generally considered to be the single, most important factor moving bankruptcy reform along."); see also Elizabeth Warren, The Changing Politics of American Bankruptcy Reform, 37 OsGOODE HALL L.J. 189, 192 (1999) (noting that in the 1997-1998 debates over bankruptcy law reform, "[t]he most stunning move was the coordination and solidification of efforts among consumer creditors"); Charles Jordan Tabb, A Century of Regress or Progress? A Political History of Bankruptcy Legislation in 1898 and 1998, 15 EMORY BANKR. DEV. J. 343, 347 (1999) (noting that pro-creditor interest groups had been actively advocating for bankruptcy reform since the early 1990s).

97. Landry, supra note 95 , at 516-17.

98. Id. at 517 . 
bankruptcies as a function of debtors attempting to evade paying their financial obligations, these creditor interest groups and other financiallending institutions spent more than $\$ 100$ million lobbying Congress for a reformation of the Code. ${ }^{99}$ In an effort to forestall the escalation in consumer-bankruptcy cases, the credit and commercial-lending industries undertook a massive, concerted campaign and lobbying effort to have the Code revamped. ${ }^{100}$

In 1996, when the number of bankruptcy filings reached the one million mark, the credit interest groups seized the opportunity to promote the need for bankruptcy reform. ${ }^{101}$ As Professor Warren recounts, "[f]uelling the fire at every opportunity and making every effort to confirm investigative reporters' worst suspicions, the lobbyists [hired by the credit industry] sent out thousands of press releases declaring that the rising tide of bankruptcy was swollen by morally slack consumers who could repay their debts." 102 The efforts of the credit industry to turn the winds of change against the individual debtor extended well beyond multiple press releases. The creditor interest groups commissioned studies to be conducted, demonstrating that debtors could in fact repay significant portions of their debts. ${ }^{103}$ Generally speaking, the studies commissioned by the credit industry assumed one of three different approaches.

99. See David K. Stein, Comment, Wrong Problem, Wrong Solution: How Congress Failed the American Consumer, 23 EMORY BANKR. DEV. J. 619, 630 (2007); see also Warren, supra note 96, at 193 ("Influence in Washington was wielded by the $\$ 300$-an-hour lobbyists on behalf of a wellorganized, well-funded creditor interest group. Other interest groups were active, but they had neither the resources nor the commitment to match the credit industry focus on consumer bankruptcy.").

100. Domowitz \& Eovaldi, supra note 91, at 804 ("As reports of the increase in bankruptcy filings were published, various creditor organizations and major consumer lenders expressed alarm and concern. They presented Congress with evidence of the impact of the Code and advanced various proposals to amend the Code in ways which would make bankruptcy more costly and less beneficial to nonbusiness debtors."). For a detailed discussion of the efforts made by the creditor community to have the Code amended in response to the rise in consumer bankruptcy filings, see Warren, supra note 96, at 194-96. See also Jean Braucher, A Fresh Start for Personal Bankruptcy Reform: The Need for Simplification and a Single Portal, 55 AM. U. L. REV. 1295, 1301-05 (2006); Landry, supra note 95, at 515-18.

101. See Landry, supra note 95, at 516 ("The great surge of bankruptcies in the 1990s provided the credit industry with ammunition to seek bankruptcy reform that would make it more difficult for people to avoid paying their debts. The surge in bankruptcy cases is generally considered to be the single, most important factor moving bankruptcy reform along.").

102. Warren, supra note 96, at 195; see also Gross, supra note 31, at 77 ("Bolstered by media attention to the rising rate of bankruptcies and by the apparent ability of individual debtors to avoid their obligations through the bankruptcy laws, the industry maintained that its recoveries were unnecessarily diminished solely because abusive debtors were manipulating the Code to their advantage." (footnote omitted)).

103. Warren, supra note 96 , at 195. 
The first approach was to quantify the amount of unrecoverable loan indebtedness as a result of individuals resorting to the bankruptcy process. ${ }^{104}$ "For example, MasterCard International and Visa USA funded a study by the Wharton Econometric Forecasting Associates Group in which the study found that bankruptcy cost the economy $\$ 44$ billion in 1997." 105 The second approach to the credit-industry studies aimed to demonstrate the decline in the stigma associated with filing for bankruptcy protection. ${ }^{106}$ Third, and most significantly, the creditindustry studies purported to show that consumer debtors could in fact repay substantial portions of their indebtedness, but instead choose to discharge their unsecured debts through the bankruptcy process. As one commentator has elucidated:

Other creditor-funded studies focused, not on the costs to the economy as a whole, but on whether bankruptcy filers could pay a portion of their debts under [a] proposed needs-based test. In 1998 Ernst and Young estimated that about $15 \%$ of Chapter 7 filers could pay about $64 \%$ of their general unsecured debt. A similar study in 1999, also conducted by Ernst and Young, found that about 10\% of Chapter 7 filers could pay about $53 \%$ of their general unsecured debt. According to the 1998 and 1999 studies, the total amount that could have been repaid was $\$ 4$ billion and $\$ 3$ billion respectively. ${ }^{10}$

Simply put, the campaign lodged by the credit industry and its minions proved to be keenly focused, well organized, and highly politicized. Their efforts proved unrelenting, insofar as the bankruptcy

104. Landry, supra note 95 , at 519

105. Id.

106. Id.

107. Id. (footnotes omitted). The commissioned studies were not, however, the end of the credit industry's campaign. The credit community hired former politicians and high-powered law firms to further their interests in achieving bankruptcy-law reform. As Professor Elizabeth Warren recounts:

Former Secretary of the Treasury and kindly senior Democrat, Lloyd Bentsen, was hired to make a public pitch for bankruptcy reform - without disclosing that he worked as a credit industry lobbyist. Former Republican National Committee Chairman, Haley Barbour, and senior Washington lawyer, Lloyd Cutler, signed on to the creditors' cause. Big law firms with little experience in consumer bankruptcy law, such as Washington's Wilmer, Cutler \& Pickering, and San Francisco's Morrison \& Forrester, dedicated teams of lawyers to writing and advising on bankruptcy laws. These teams were often staffed and led by corporate lawyers with no experience in consumer bankruptcy. Advertising agencies developed campaigns to illustrate the cost of bankruptcy to ordinary families, as the consumer credit industry took out full page advertisements in Washington-area newspapers. Lobbyists were available for every talk show, to call every editorial staff and consumer affairs reporter, and to respond to every unfavourable story in the press. Messages and themes were developed, so that the same quotes appeared with multiple attributions. All in all, it was a well-orchestrated campaign.

Warren, supra note 96, at 195-96. 
system was portrayed to the public as being abused by wealthy debtors who shunned their moral responsibilities to repay their debts and instead opted to file for bankruptcy protection. Moreover, the credit industry shrewdly framed the issue of resorting to bankruptcy as a systemic problem that caused harm to everyone's collective financial well-being. Contrary to the credit industry, the community representing the interests of debtors did not have the finances or political clout to mount an opposing campaign. It is no doubt tremendously difficult to organize diffuse individuals who may have a common interest (that is, to the extent they can forecast a slide into bankruptcy), but no ability to communicate with one another ex ante about their common financial concerns. Consequently, after more than approximately twelve years of vigorous lobbying efforts, the credit industry found a receptive ear in Congress in the early 2000s, and an overhaul of the Code commenced. The result was the enactment of BAPCPA in 2005, a controversial topic to which this Article now turns.

\section{THE ENACTMENT OF BAPCPA AS ANTI-DEBTOR LEGISLATION}

The principles and policies of bankruptcy law can be viewed historically, in part, as a result of the dominant political climate. ${ }^{108}$ This notion was borne out on April 20, 2005, when President Bush signed BAPCPA into law. By all observers' accounts, the day marked a significant turning point in the direction and dynamics of consumer bankruptcy in the United States. ${ }^{109}$ As noted, after approximately a dozen years of concerted lobbying efforts, the credit industry and financial lending institutions found a sympathetic ear in Congress and the White House. More poignantly, though, and as Professor Tabb commented, "[t]he enactment of BAPCPA marked the successful culmination of over two score years of intense, fervent, and well-funded

108. See Warren, supra note 96, at 190 ("Since the discretion of the legislative body shapes the bankruptcy system, bankruptcy laws can be understood, not only as a function of the internal intellectual coherence of the economic system, but as a function of the politics of adoption.").

109. See Ralph Brubaker, Consumer Credit and Bankruptcy: Assessing a New Paradigm, 2007 U. ILL. L. REV. 1, 1 (“Congress's enactment of [BAPCPA] has wrought the most significant revision of the bankruptcy relief available to individual debtors in over 100 years."); Ronald J. Mann, Bankruptcy Reform and the "Sweat Box" of Credit Card Debt, 2007 U. ILL. L. REV. 375, 376 (noting that BAPCPA "radically altered the policies underlying consumer bankruptcy in this country, marking a significant shift in favor of creditors"); Eugene R. Wedoff, Major Consumer Bankruptcy Effects of BAPCPA, 2007 U. ILL. L. REV. 31, 31 ("The Bankruptcy Abuse Prevention and Consumer Protection Act... dramatically changed several aspects of individual consumer bankruptcy law.”). 
lobbying by the consumer credit industry."110 In other words, the credit industry won, and future debtors lost.

By and large, the rationale for the enactment of BAPCPA was "to curtail alleged consumer abuses arising from the previous quarter century of bankruptcy reform."111 Stated slightly differently, BAPCPA purportedly stands as a corrective remedy to stem the tide of abusive consumers "gaming" the system by resorting to bankruptcy relief and failing to pay their debts. Nothing could be further from reality. What is more remarkable about the enactment of BAPCPA is that Congress itself recognized that abuse of the bankruptcy system was limited to only a few outliers. The House Judiciary Committee Report accompanying the legislation affirmatively notes that "abuse in the system is not widespread and that most bankruptcy filings result from causes beyond debtors' control, such as family illness, job loss or disruption, or divorce."112 Bowing to the special interests of the credit industry is perhaps the only sensible rationale for the enactment of BAPCPA. ${ }^{113}$ In part, the theory of consumer utility advanced in this Article serves to counterbalance this political power inequality by advocating for a broader consumer-bankruptcy discharge for debtors who do not run afoul of $\S 727$ of the Code.

110. Charles J. Tabb, The Top Twenty Issues in the History of Consumer Bankruptcy, $2007 \mathrm{U}$. ILL. L. REV. 9, 9.

111. Thomas Bak et al., A Comparison of the Effects of the 1978 and 2005 Bankruptcy Reform Legislation on Bankruptcy Filing Rates, 25 EMORY BANKR. DEV. J. 11, 11 (2008).

112. H.R. REP. NO. 109-31, pt.1, at 4 (2005) reprinted in 2005 U.S.C.C.A.N. 88, 91.

113. Almost every bankruptcy-law scholar has criticized BAPCPA in one form or another. See, e.g., Jean Braucher, A Guide to Interpretation of the 2005 Bankruptcy Law, 16 AM. BANKR. INST. L. REV. 349, 349 (2008) (referring to BAPCPA as a "defectively designed and poorly drafted mess"); Margaret Howard, The Law of Unintended Consequences, 31 S. ILL. U. L.J. 451, 451 (2007) ("My purpose is to talk about the 2005 Amendments and how things are going with the new provisions. But where do you start, with a bad law?"). Criticisms of BAPCPA have also found expression in judicial decisions. For example, in In re Sosa, the United States Bankruptcy Court for the Western District of Texas stated as follows regarding BAPCPA:

The Congress of the United States of America passed and the President of the United States of America signed into law the Bankruptcy Abuse Prevention and Consumer Protection Act of 2005 (the "Act"). It became fully effective on October 17, 2005. Those responsible for the passing of the Act did all in their power to avoid the proffered input from sitting United States Bankruptcy Judges, various professors of bankruptcy law at distinguished universities, and many professional associations filled with the best of the bankruptcy lawyers in the country as to the perceived flaws in the Act. This is because the parties pushing the passage of the Act had their own agenda. It was apparently an agenda to make more money off the backs of the consumers in this country. It is not surprising, therefore, that the Act has been highly criticized across the country. In this writer's opinion, to call the Act a "consumer protection" Act is the grossest of misnomers.

In re Sosa, 336 B.R. 113, 114 (Bankr. W.D. Tex. 2005). 
Although BAPCPA caused substantive changes in the Code effecting both consumer bankruptcies and traditional business restructurings, the overwhelming public fanfare and publicity surrounded - and continues to surround - the changes to Chapter 7 and Chapter 13 of the Code, predominantly the province of individual debtors. It is beyond the scope of this Article to detail all of the changes to the consumer-bankruptcy system wrought by BAPCPA; however, to date a wealth of scholarly literature already exists examining the substantive amendments in BAPCPA along with the anticipated consequences to consumerbankruptcy law. ${ }^{114}$ The passage of BAPCPA unjustifiably shifted the balance of rights in the consumer-bankruptcy context decisively in favor of creditors, and as a consequence of the legislative amendments thereto, seriously threatens the eradication of the fresh start policy for those in need. A brief examination of the most critical amendments in the legislation bears this out.

The most infamous alteration of the Code as a result of BAPCPA, and in direct response to the desires of the credit industry, is the "means test" contained in $\S 707(\mathrm{~b}) .{ }^{115}$ The means test was implemented with the aim of restricting eligibility for relief under Chapter 7 of the Code and forcing more debtors into Chapter 13 repayment plans. Section 707(b)(1) provides in part that the bankruptcy court may dismiss a Chapter 7 case filed by an individual whose debts are primarily consumer debts, ${ }^{116}$ or, with the consent of the debtor, the court can convert the case to a Chapter 13 proceeding if the court finds that continuing the Chapter 7 case would constitute "abuse." "117 In short, the means test requires the bankruptcy trustee to examine the income and expenses of most individual debtors. As amended, $\S 707(\mathrm{~b})$ of the Code requires a court to presume abuse of Chapter 7 if the amount of the debtor's remaining income, after specified expenses and other amounts

114. See, e.g., Braucher, supra note 100; Braucher, supra note 113; Jean Braucher, The Challenge to the Bench and Bar Presented by the 2005 Bankruptcy Act: Resistance Need Not Be Futile, 2007 U. ILL. L. REv. 93; Howard, supra note 113; Robert M. Lawless, The Paradox of Consumer Credit, 2007 U. ILL. L. REv. 347; Mann, supra note 109; Tabb, supra note 32; Tabb, supra note 110; Wedoff, supra note 109.

115. See Tabb, supra note 32, at 12 ("Imposition of a means test has been the Holy Grail sought by the consumer credit industry for over a third of a century."); see also 11 U.S.C. § 707(b) (2006). The means test is also incorporated in Chapter 13, whereby above median-income debtors must calculate the amounts necessary to fund their plans in accordance with the standards found in $\S$ 707(b). See 11 U.S.C. § 1325(b) (2006).

116. Section 101(8) of the Code defines "consumer debt" to mean a debt "incurred by an individual primarily for a personal, family, or household purpose." 11 U.S.C. § 101(8) (2006). The upshot of the definition is that most every consumer debtor will be impacted by the means test.

117. $§ 707(b)(1)$. 
are deducted ${ }^{118}$ from the debtor's "current monthly income," 119 when multiplied by sixty, exceeds the lower of the following: "(I) 25 percent of the debtor's nonpriority unsecured claims in the case, or $\$ 6,575$, whichever is greater or (II) $\$ 10,950 . " 120$

When reduced to practical figures, the consequences of the means test are dramatic. For those individual debtors whose "current monthly income" is less than $\$ 100$ after the defined deductions are considered, no presumption of abuse under the means test arises and the debtor can remain in Chapter 7, assuming the debtor survives an arguably secondlayered abuse test contained within $\S 707(\mathrm{~b})(3) .{ }^{121}$ If a debtor has "current monthly income" of $\$ 100$ after the requisite expenses and deductions are considered, a presumption of abuse arises unless the outstanding debt exceeds $\$ 24,000 .{ }^{122}$ Further, if the debtor's "current monthly income" after the available expenses are deducted is between $\$ 150$ and $\$ 166.66$ - nothing more than a single trip to the grocery store - a presumption of abuse arises unless the overall debt exceeds approximately $\$ 36,000$ to $\$ 39,998 .^{123}$ Finally, if the "current monthly income" is more than $\$ 166.66$ after available deductions, a presumption of abuse always arises. ${ }^{124}$ Under the means test, a presumption of abuse may be rebutted only by the debtor demonstrating "special circumstances, such as a serious medical condition," and "to the extent

118. The permitted expenses and deductions are tied to the Internal Revenue Service guidelines for national and local living standards. See $\S 707(b)(2)(A)$.

119. The Code defines "current monthly income" in part to mean

the average monthly income from all sources that the debtor receives (or in a joint case the debtor and the debtor's spouse receive) without regard to whether such income is taxable income, derived during the 6-month period ending on-(i) the last day of the calendar month immediately preceding the date of the commencement of the case if the debtor files the schedule of current income required by section 521(a)(1)(B)(ii); or (ii) the date on which current income is determined by the court for purposes of this title if the debtor does not file the schedule of current income required by section 521(a)(1)(B)(ii) ....

$\S 101(10 \mathrm{~A})$.

120. $\S 707(\mathrm{~b})(2)(\mathrm{A})(\mathrm{i})$.

121. Section 707(b)(3) of the Code provides as follows:

In considering under paragraph (1) whether the granting of relief would be an abuse of the provisions of this chapter in a case in which the presumption in subparagraph (A)(i) of such paragraph does not arise or is rebutted, the court shall consider-(A) whether the debtor filed the petition in bad faith; or (B) the totality of the circumstances (including whether the debtor seeks to reject a personal services contract and the financial need for such rejection as sought by the debtor) of the debtor's financial situation demonstrates abuse.

$\S 707(\mathrm{~b})(3)$

122. Wedoff, supra note 109 , at 52

123. Id.

124. Id. 
such special circumstances that justify additional expenses or adjustments of current monthly income for which there is no reasonable alternative." 125

A study conducted by Professor Jean Braucher concludes that in practice, the means test only affects a "small" number of debtors in Chapter 7 and Chapter 13. ${ }^{126}$ According to Professor Braucher, "only eight or nine percent of Chapter 7 debtors" have an income above the median income for the particular state of filing, the condition precedent for triggering the means test. ${ }^{127}$ To complement Professor Braucher's findings, a recent empirical study conducted by a group of academics in several different disciplines concluded that BAPCPA does not have the result Congress intended, namely, forcing high-income earners into Chapter 13 repayment plans. ${ }^{128}$ As these scholars conclude, the individuals filing for bankruptcy are not high-income earners shirking their contractual obligations, but rather individuals and families struggling with insurmountable debt loads. ${ }^{129}$

But while the means test admittedly affects a minority of consumer debtors filing for either Chapter 7 or Chapter 13, even Professor Braucher concedes that the means test still produces "quite a volume of cases." 130 As Professor Braucher opined in her own examination of BAPCPA, if one assumes

a million consumer bankruptcy filings per year, 666,000 in Chapter 7 and 340,000 in Chapter 13-figures that approximate 2008 filing levels - and assuming eight percent are above median income in Chapter 7 and twenty-seven percent are above median income in Chapter 13, that means there are about 53,000 Chapter 7 cases and nearly 92,000 Chapter 13 cases a year in which presumed abuse means testing matters.

And while a portion of these debtors will satisfy the means test to remain in Chapter 7 or not be chained to a disposable income calculation in Chapter 13, it remains that tens of thousands of Chapter 7 debtors per

125. $§ 707(b)(2)(B)(i)$.

126. Braucher, supra note 113 , at 378 .

127. Id. at 383 .

128. Lawless et al., supra note 9, at 361 .

129. Id. at 373 ("In sum, when looking at measures beyond just income, the families filing for bankruptcy today are in worse shape than those filing in earlier years. Family by family, median net worth continues to sink, and bankrupt households are struggling with ever-larger mortgages and total debt loads.").

130. Braucher, supra note 113, at 384 .

131. Id. (footnotes omitted) (emphasis added). 
year are in danger of being deprived of their discharge, and tens of thousands of Chapter 13 debtors per year are in danger of failing to receive their delayed discharges by mandated repayment plans that later prove infeasible. ${ }^{132}$ As the great swath of scholarly literature overwhelmingly demonstrates, these debtors are not spendthrifts attempting to evade their financial obligations, but moderate income debtors and their families trying to survive everyday life. ${ }^{133}$

A second change in BAPCPA affecting most consumer debtors concerns the dischargeability of credit-card debt in either Chapter 7 or Chapter 13 of the Code. Pursuant to $\S 523(\mathrm{a})(2)(\mathrm{A})$, a discharge in either Chapter 7 or Chapter 13 does not discharge a debt "for money, property, services, or an extension, renewal, or refinancing of credit, to the extent obtained-(A) by false pretenses, a false representation, or actual fraud ...."134 For purposes of this section, BAPCPA prescribes that "consumer debts owed to a single creditor and aggregating more than $\$ 550$ for luxury goods or services incurred by an individual debtor on or within 90 days before the order for relief under this title are presumed to be nondischargeable." "135 Moreover, pursuant to $\S 523(\mathrm{a})(2)(\mathrm{A})$, "cash advances aggregating more than $\$ 825$ that are extensions of consumer credit under an open end credit plan [(e.g., a credit card)] obtained by an individual debtor on or within 70 days" before the bankruptcy filing are presumed to be nondischargeable. ${ }^{136}$ Lastly, for purposes of this exception to discharge, the Code defines "luxury goods or services" to not include goods or services "reasonably necessary for the support or maintenance of the debtor or a dependent of the debtor." 137

How, then, does $\S 523(\mathrm{a})(2)(\mathrm{A})$ fit into credit-card debt and impinge upon an individual debtor's complete fresh start? To begin, credit-card debt comprises a significant amount of the total aggregate indebtedness in most every consumer-bankruptcy case. ${ }^{138}$ This is possibly the reason that institutional credit-card lenders will often object to a consumer

132. Pursuant to $\S 1328$ (a) of the Code, a Chapter 13 debtor does not receive a discharge until all payments contemplated by the three- to five-year plan are made. See 11 U.S.C. $§ 1328$ (a) (2006).

133. See generally SULLIVAN ET AL., supra note 36; WARREN \& TYAGI, supra note 36; Braucher, supra note 113; Braucher, supra note 100; Lawless et al., supra note 9; Porter \& Thorne, supra note 44; Charles Jordan Tabb, The Death of Consumer Bankruptcy in the United States?, 18 EMORY BANKR. DEV. J. 1 (2002); Warren, Financial Collapse and Class Status, supra note 36; Warren, The Growing Threat, supra note 36; Warren, The Bankruptcy Crisis, supra note 36.

134. $§ 523(\mathrm{a})(2)(\mathrm{A})$.

135. $§ 523(\mathrm{a})(2)(\mathrm{C})(\mathrm{i})(\mathrm{I})$.

136. § 523(a)(2)(C)(i)(II)

137. § 523(a)(2)(C)(ii)(II).

138. Singer, supra note 43 , at 336. 
debtor's discharge of these particular debts using $\S 523(\mathrm{a})(2)(\mathrm{A})$ of the Code.

Responding to this objection, courts have adopted an "implied representation" theory with respect to a debtor's election to receive a credit card and have the issuer extend credit on his or her behalf. Because the debtor makes no actual representation to the creditor when using a credit card, and the issuer does not contemporaneously rely on any representation by the debtor, courts hold that a debtor's use of a credit card amounts to an implied representation of an intention to repay the charges incurred. ${ }^{139}$ Other courts interpret $\S 523(\mathrm{a})(2)(\mathrm{A})$ more broadly, holding that a credit-card debtor implicitly represents both the intent and the ability to repay the credit-card issuer. ${ }^{140}$

Moreover, because determining whether a debtor subjectively intended to repay the debt is most often a futile inquiry, courts utilize a "totality of the circumstances" standard to construe a debtor's state of mind. ${ }^{141}$ Courts frequently consider the following factors to be relevant in determining the debtor's intent:

1. The length of time between when the charges were made and the bankruptcy filing;

2. Whether an attorney was consulted concerning the filing of bankruptcy before the charges were made;

3. The number of charges made;

4. The amount of the charges;

5. The debtor's financial condition at the time the charges were made;

6. Whether the charges were above the account's credit limit;

7. Whether the debtor made multiple charges on the same day;

139. See, e.g., Chase Bank USA, N.A. v. Ritter (In re Ritter), 404 B.R. 811, 824 (Bankr. E.D. Pa. 2009); see also Chase Bank USA, N.A. v. Swanson, 398 B.R. 328, 335 (Bankr. N.D. Iowa 2008) ("Bankruptcy law provides that use of a credit card constitutes an implied representation of the cardholder's intent to repay the charges."); G.E. Money Bank v. Wyble (In re Wyble), 387 B.R. 603, 607 (Bankr. W.D. Mo. 2008) (holding same).

140. Ritter, 404 B.R. at 824 .

141. Chase Bank v. Brumbaugh (In re Brumbaugh), 383 B.R. 907, 912-13 (Bankr. N.D. Ohio 2007); see also MBNA Am. Bank, N.A. v. Hostetter (In re Hostetter), 320 B.R. 674, 685 (Bankr. N.D. Ind. 2005) ("In determining whether debts were incurred with no intention to repay them, many courts look at the totality of circumstances."). 
8. Whether the debtor was employed;

9. The debtor's prospects for employment;

10 .The debtor's financial sophistication;

11. Whether there was a sudden change in the debtor's buying habits; and

12. Whether the purchases were made for luxuries. ${ }^{142}$

As can be discerned from the multiplicity of factors courts consider, this inquiry is made on an ad hoc basis. As a result, both consumer debtors and their credit card issuers lack any level of certainty as to whether the debtor will successfully discharge a critical portion of his or her overall indebtedness. Ironically, because courts consider the debtor's financial condition and employment status at the time the charges were made, it is eminently conceivable that the debtors who need to rely on credit cards during a time of crisis-e.g., loss of employment or unexpected medical condition-are the very same debtors who could be denied a discharge of their credit-card debt for fraud.

BAPCPA also amended the time intervals between discharges and made a Chapter 13 discharge unavailable under certain circumstances. Prior to BAPCPA, a debtor was prohibited from receiving a discharge in a Chapter 7 case if he or she had received such a discharge during the preceding six years. ${ }^{143}$ Through $\S 727(\mathrm{a})(8)$ of the Code, BAPCPA increased the time interval between Chapter 7 discharges to once every eight years. ${ }^{144}$ In the Chapter 13 context, BAPCPA introduced a prohibition on receiving a discharge in a subsequent Chapter 13 case if the debtor had received either a Chapter 7 discharge during the preceding four-year period or a Chapter 13 discharge in the preceding two years. ${ }^{145}$

Finally, to a limited degree, BAPCPA made it more difficult for consumers to discharge student-loan debt. Admittedly, the dischargeability of student loans has been a controversial issue since before the enactment of the Code in 1978. But the issue remains of vital

142. Ritter, 404 B.R. at 826 .

143. See 11 U.S.C. $\S 727(a)(8)$ (2006) (stating that the court shall grant the debtor a discharge unless "the debtor has been granted a discharge ... in a case commenced within six years before the date of the filing of the petition").

144. See $\S 727(a)(8)$ (stating that the court shall grant the debtor a discharge unless "the debtor has been granted a discharge ... in a case commenced within 8 years before the date of the filing of the petition").

145. §1328(f). 
importance because today's college students may be unable to repay student loans at unprecedented levels. As a recent book describes, the current higher education regime can be viewed as a "debt-for-diploma" system. ${ }^{146}$ In the recent past, approximately two-thirds of all college financial aid took the form of grants; today, two-thirds originates from loans. ${ }^{147}$ Further, tuition at public universities has risen approximately $122 \%$ over the past twenty years. ${ }^{148}$ The upshot is that for many college students, obtaining a four-year degree-not to mention a graduate degree - requires the incurrence of substantial debt.

As one commentator recounts:

Prior to 1977, there was no provision in the bankruptcy laws regarding the dischargeability of educational loans. Section 523(a)(8) was enacted with the promulgation of the Bankruptcy Code in 1978 in response to the perception that a growing tide of students were abusing the bankruptcy laws by discharging large amounts of educational indebtedness shortly after leaving school, despite having well-paying jobs and few other debts. To the extent that a failure to repay student loans would have an adverse impact upon funds available for future generations of students, it was thought that the national interest in providing educational assistance through student loan programs would be seriously undermined. Thus, safeguarding the integrity of the student loan programs while curtailing the ability of student borrowers to unfairly exploit its benefits were the twin objectives of the legislation.

Section 523(a)(8) of the Code creates a presumption of nondischargeability for educational loan debt. ${ }^{150}$ Prior to BAPCPA, only government-sponsored educational loans were encompassed by $\S$ 523(a)(8); stated differently, private educational loans were likely

146. José García ET AL., Up TO OUR Eyeballs: How SHADY LENDERS AND FAILED ECONOMIC Policies ARE DROWNING AMERICANS IN DEBT 92 (2008).

147. Id. at 99 .

148. Id.

149. Singer, supra note 43, at 387 (footnotes omitted).

150. Section 523(a)(8) provides as follows:

(a) A discharge under section 727, 1141, 1228(a), 1228(b), or 1328(b) of this title does not discharge an individual debtor from any debt-(8) unless excepting such debt from discharge under this paragraph would impose an undue hardship on the debtor and the debtor's dependents, for-(A)(i) an educational benefit overpayment or loan made, insured, or guaranteed by a governmental unit, or made under any program funded in whole or in part by a governmental unit or nonprofit institution; or (ii) an obligation to repay funds received as an educational benefit, scholarship, or stipend; or (B) any other educational loan that is a qualified education loan, as defined in section 221(d)(1) of the Internal Revenue Code of 1986, incurred by a debtor who is an individual. 
dischargeable through the bankruptcy process. Under BAPCPA, however, "both government-sponsored and private student loans are nondischargeable" in Chapter 7 and Chapter 13 cases. ${ }^{151}$ While this may appear trivial at first, an increasing amount of student-loan debt arises from private lending institutions as the cost of tuition skyrockets.

A debtor seeking to discharge student-loan debt falling under $\S$ 523(a)(8) has the burden of demonstrating that "excepting the debt from discharge will cause the debtor and his or her dependents to experience "undue hardship." 152 Under the so-called Brunner test ${ }^{153}$ for undue hardship, a debtor seeking to discharge his or her student loans must prove that:

(1) based on current income and expenses, the debtor cannot maintain a "minimal" standard of living for herself and her dependents if forced to repay the loans; (2) additional circumstances exist indicating that this state of affairs is likely to persist for a significant portion of the repayment period for the student loans; and (3) the debtor has made a good faith effort to repay the loans. ${ }^{154}$

Much like the standard for evaluating the dischargeability of creditcard debt, some courts adopt a totality of the circumstances standard for determining whether the nondischargeability of the educational loan debt will result in "undue hardship." These courts consider the following: "“(1) the debtor's past, present, and reasonably reliable future financial resources; (2) a calculation of the debtor's and his or her dependent's reasonable necessary living expenses; and (3) any other relevant facts and circumstances surrounding each particular bankruptcy case." $" 155$ At essence, $\S 523(\mathrm{a})(8)$ requires that bankruptcy courts utilize a certain amount of discretion to determine "how much personal sacrifice society expects from individuals who accepted the benefits of guaranteed student loans but who have not obtained the financial rewards they had expected to receive as a result of their educational expenditures."

151. In re Orawsky, 387 B.R. 128, 144 n.26 (Bankr. E.D. Pa. 2008).

152. Miller v. Sallie Mae, Inc. (In re Miller), 409 B.R. 299, 307 (Bankr. E.D. Pa. 2009).

153. Brunner v. N.Y. State Higher Educ. Servs. Corp., 831 F.2d 395 (2d Cir. 1987).

154. Miller, 409 B.R. at 303.

155. Halverson v. U.S. Dep't of Educ. (In re Halverson), 401 B.R. 378, 384 (Bankr. D. Minn. 2009) (quoting Long v. Educ. Credit Mgmt. Corp. (In re Long), 322 F.3d 549, 554 (8th Cir. 2003)).

156. 4 COLLIER ON BANKRUPTCY 9523.14 [2] (15th ed. 2007). 


\section{EXISTING SCHOLARLY THEORIES OF THE CONSUMER DisCHARGE}

Ever since the concept of a discharge of one's indebtedness first appeared in Anglo-American jurisprudence more than three centuries ago, scholars, commentators, legislators, and judges have vigorously debated over whether a discharge should be available at all, and if so, what policy justification exists for relieving a debtor of the contractual obligation to repay a valid debt. In the past twenty-five years, modern scholars have advanced several competing theories for justifying the consumer discharge; these normative explanations will be examined below.

\section{A. The "Debtor Cooperation" Theory}

The debtor-cooperation theory, offered by Professor Tabb, provides a historical justification for the consumer-bankruptcy discharge. Under this theory, the discharge is "a carrot dangled in front of debtors to induce them to cooperate with the trustee and the creditors in the bankruptcy case in the location, collection, and liquidation of the debtor's assets." 157 This theory was the primary justification for offering the earliest discharge in England and in the American Bankruptcy Act of 1800. ${ }^{158}$ Simply put, if the debtor cooperated to the satisfaction of the creditors, then the debtor received a discharge; if not, the discharge was denied. ${ }^{159}$ At this time in Anglo-American jurisprudence, the bankruptcy laws were focused entirely on maximizing the recovery for creditors, and not upon the rehabilitation of the downtrodden debtor. ${ }^{160}$ This concept is underscored by the fact that in order for a debtor to receive a discharge of debt during this period of time, even if he or she fully cooperated with the creditors, the creditor body had to affirmatively consent to the awarding of the discharge by at least a majority, if not by two-thirds creditor vote. ${ }^{161}$

The debtor-cooperation theory still exists today in the embodiment of $\S 727$ of the Code. ${ }^{162}$ As noted earlier, if the debtor, for example, fails to disclose fully his or her assets or fails to obey a court order to turn over

\footnotetext{
157. Tabb, supra note 49 , at 90 .

158. Id. at 91 .

159. Id. at 90 .

160. See id. at 91, n.261 (compiling authority that the earliest discharges were offered to further creditors' interests).

161. Id. at 91 .

162. See generally 11 U.S.C. $\S 727$ (2006).
} 
non-exempt assets to the bankruptcy trustee, then a court can deny the debtor a global discharge of all pre-petition debt. ${ }^{163}$ That said, however, perhaps the most significant detraction to the debtor-cooperation theory is the difficulty in justifying it in light of $\S 523(\mathrm{a})$ of the Code. From the Bankruptcy Act of 1800 to the enactment of BAPCPA, the list of debts specifically excepted from discharge has gradually expanded. ${ }^{164}$ More particularly, debts excepted from discharge today, at least presumptively, include student loans and credit cards - categories of debt that drown many debtors.

If this is the case, then allowing creditors to obstruct a debtor's complete discharge creates a disincentive for debtors to cooperate voluntarily in the bankruptcy case, a necessary condition for the successful operation of the entire bankruptcy process. This disincentive is magnified by the fact that in most every bankruptcy case, the bankruptcy trustee or the court has no concrete way of verifying whether the debtor has been completely truthful in the petition and schedules regarding the real and personal property the debtor possesses. Stated slightly differently, neither the trustee nor the court undertakes a physical inventory or search for all of the debtor's possessions. Therefore, the incentive is great for debtors who are burdened with credit-card debt, student-loan debt, or any other type of debt potentially excepted from discharge to improperly shelter assets from the reach of the bankruptcy system.

\section{B. "Impulse Control" and "Incomplete Heuristics" Theories}

Over twenty years ago, Professor Thomas H. Jackson offered two underlying theories for the consumer discharge, premised upon "volitional and cognitive justifications," 165 both paternalistic in nature. ${ }^{166}$ The first theory advanced by Professor Jackson is a volitional justification premised upon the notion of "impulse control." "167 Professor

163. Id.

164. See $\S 523$ (a) (declaring certain types of debt to be excepted from discharge).

165. Jackson, supra note 42, at 1405-06.

166. The notion of paternalistic protection of the consumer as a justification for the bankruptcy discharge may once again prove in vogue given the Obama Administration's recent proposal of creating a new federal agency, the Consumer Financial Protection Agency, which would, if adopted, "dictate standards for some [financial] products before banks could bring them to market, and push banks to favor plain vanilla loans over more exotic home loans, which could be required to carry warnings." Andrew Martin \& Louise Story, Banks Brace for Fight Over an Agency Meant to Bolster Consumer Protection, N.Y. TIMES, June 18, 2009, at B6.

167. Jackson, supra note 42 , at 1408. 
Jackson argues that "people, like animals, exhibit a tendency to choose current gratification over postponed gratification, even if they know that the latter holds in store a greater measure of benefits." 168 Because of this psychological tendency towards immediate gratification, Professor Jackson believes the bankruptcy discharge serves as a control mechanism for people's impulsive behavior to incur debt without fully accounting for or appreciating the later harmful effects such indebtedness may have on their financial well-being. ${ }^{169}$ On this note, Professor Jackson contends:

If unrestrained individuals would generally choose to consume today rather than save for tomorrow, and if this tendency stems in part from impulse, they may opt for a way of removing or at least restricting that choice. If individuals cannot control the impulse themselves, they may want the assistance of a socially imposed rule, one that will simply enforce the hypothesized decisions of their fully rational selves. ${ }^{170}$

To support his theory of impulse control, Professor Jackson characterizes the individual consumer as "an addict, unable to consider or plan for the future." 171 The theory proves problematic for two reasons. First, Jackson fails to define what he means by consumption. That is, are these irrational individuals buying unnecessary wide-screen televisions, or are they incurring credit-card debt to pay for groceries or medical bills? The empirical studies conducted by Professor Warren and others, which have largely gone unchallenged, suggest otherwise: namely, that the typical consumer debtor is borrowing from Peter to pay Paul. ${ }^{172}$ Second, and closely associated with the first critique, Professor Jackson's impulse control theory is palatable only if the incurrence of debt is not necessary for everyday survival. In other words, the now cash-strapped debtor is generally not someone who irrationally over-indulged in the enticement of consumerism like a starving dog gobbles a bowl of food. Instead, incomes are not keeping pace with rising expenses, medical costs have skyrocketed (even for the luckily insured), and over-inflated home valuations force many to incur significant mortgage debt for only a modest home.

Professor Jackson's second justification for the consumer discharge, one based on cognitive processes, is identified as a theory of "incomplete

\footnotetext{
168. Id.

169. Id. at 1409 .

170. Id. (footnote omitted).

171. Id. at 1408.

172. See supra note 36 and accompanying text.
} 
heuristics."173 Admittedly an enticing theory, Jackson argues that the consumer discharge is needed because individual consumers, when making credit decisions, systematically underestimate future risks and overestimate future success. ${ }^{174}$ More specifically, Professor Jackson contends that in hindsight, if individuals were aware of their incomplete knowledge regarding their future financial prospects, they would certainly want "a system that would make some of the consequences of their borrowing avoidable."175 For Jackson, the discharge serves this function by freeing individuals from the adverse effects of incomplete heuristics. ${ }^{176}$

However, as Professor Tabb recognized, Jackson's “volitional and cognitive arguments... do not readily account for the discharge exceptions" contained within $\S 523$ of the Code. ${ }^{177}$ If, as Jackson suggests, individuals cannot control their impulses or they routinely underestimate the risks associated with incurring debt, and correspondingly overestimate the chances of future success, then precluding the complete discharge for such significant debts like student loans and credit cards does not offer much in the way of correcting for these asserted deficiencies.

\section{The Humanitarian Theory of the Consumer Discharge}

A third major justification for the consumer discharge is premised upon principles of humanitarianism. In modern bankruptcy law scholarship, the humanitarian theory is probably best associated with Professors Karen Gross and Richard E. Flint. ${ }^{178}$ As the name suggests, the humanitarian theory is premised upon the notions that forgiveness of indebtedness and a demonstration of mercy toward individuals inundated with debt are appropriate justifications for having a consumerbankruptcy discharge. According to Professor Gross, forgiveness of indebtedness is appropriate if four preconditions are met: (i) "there must

173. Jackson, supra note 42, at 1410. To Professor Jackson, in this context, "'heuristics' refers to the tools that individuals employ in processing and assessing information." See id. at 1411.

174. Id. at 1410 .

175. Id. As Jackson states, "Much evidence indicates that the errors associated with incomplete heuristics, especially anchoring, lead decisionmakers systematically to overestimate chances of success and to underestimate the corresponding risks." Id. at 1411-12.

176. Id. at 1414.

177. See Tabb, supra note 49 , at 100.

178. See generally GROSS, supra note 38 (arguing for a social welfare underpinning of bankruptcy); Flint, supra note 42 (addressing moral justifications for debtor financial relief provisions in bankruptcy). 
be a wrong committed"; (ii) "the wrong must harm another"; (iii) "the wronged party resents what occurred"; and (iv) "the wrongdoer acknowledges the wrong done and takes steps to rectify it." ${ }^{\text {179 }}$ By extrapolation, Professor Gross contends that these conditions are found in the bankruptcy dynamic. That is, the "wrong" is the debtor's failure to pay legitimate financial obligations, ${ }^{180}$ the non-payment of the debt harms creditors who are not paid for their goods or services, or who are deprived of an investment that would have yielded a profit; the creditors harmed by the debtor's failure to honor his or her contractual obligations certainly resent such conduct; ${ }^{181}$ and, by filing for bankruptcy protection, a debtor acknowledges publicly his or her failure. ${ }^{182}$

According to this aspect of the humanitarian theory, forgiving indebtedness serves a restorative function for both debtors and creditors alike. The consequences of filing for bankruptcy protection-and the subsequent scrutiny into the debtor's personal and financial affairsenable the "wronged" creditors "to feel that the disequilibrium created by nonpayment has been at least partially restored." 183 For the debtor, the transformative power of the bankruptcy process provides him or her with "the opportunity to regain self-esteem and become once again a productive member of society." 184

Professor Flint's take on the humanitarian theory of the consumer discharge is grounded in a natural law theory of morality. ${ }^{185}$ According to Professor Flint, the consumer-bankruptcy system in American society has evolved from one of retaliation and punishment, to compensation for creditors, to "compassion and concern for the less fortunate in our society." " As Professor Flint argues, through this evolutionary process, the discharge of the consumer debtor recognizes the inherent dignity of every human to be afforded an opportunity to earn a living and puts him or her back on the road to self-determination. ${ }^{187}$ In short, under the

\footnotetext{
179. GRoss, supra note 38 , at 93.

180. Id.

181. Id. at $93-94$

182. Id at 94 .

183. Id.

184. Id

185. Flint, supra note 42, at 519-20. As Professor Flint states: "By stressing that the law reflects reason and conscience, this article should convince even the skeptic that fundamental principles of fairness and humanitarianism form the moral dimension of the debtor relief provisions of the Bankruptcy Code." Id. at 526.

186. Id. at 554 .

187. In Professor Flint's words:

The debtor relief process can be viewed as congressional recognition that the intrinsic value of human dignity dictates that a debtor be given an opportunity to earn a living.
} 
humanitarian theory of discharge, oppressive debt obligations undermine a debtor's sense of self-worth; by freeing the debtor of these financial constraints, a debtor theoretically regains his or her sense of selfworth. ${ }^{188}$

Critiques of the humanitarian theory have found expression in the existing scholarly literature, and thus will not be recounted at length. ${ }^{189}$ Nonetheless, Professor Tabb raises two interesting theoretical questions engendered by the humanitarian theory that have not yet been addressed by its proponents: "First, should the creditor's consent (or lack thereof) to participate in the societal forgiveness scheme be considered at all in the equation? Second, should the debtor have to be deserving in some fashion to be able to appropriate for himself society's discharge gift?" 190 Despite the critiques of the humanitarian theory of consumer discharge, the main goals advanced by the theory, restoring a sense of self-worth and the freeing of human capital, have direct applicability to the theory of consumer utility advanced by this Article, as will be demonstrated below.

\section{The Economic Theory of the Consumer Discharge}

An economic theory for the consumer discharge is perhaps best associated with the work of Professors Margaret Howard and John M. Czarnetzky. Professor Howard advocates a theory of discharge in straightforward, yet powerful terms. That is, the underlying justification for the discharge is "to restore the debtor to participation in the open credit economy." 191 Implicit in Professor Howard's theory is that the availability of a discharge incentivizes a debtor who has become idle in his or her occupation - presumably because the income generated from working primarily benefits existing creditors - to return once again to his or her optimally producing self.

The freeing of human capital provides an individual debtor with the ability to maintain a minimum standard of living and puts him back on the road to self-determination. Thus, discharge is an acknowledgment by Congress that the dignity of the individual person has value.

Id. at 536 (footnote omitted).

188. Tabb, supra note 49 , at 95 .

189. See, e.g., Jason J. Kilborn, Mercy, Rehabilitation, and Quid Pro Quo: A Radical Reassessment of Individual Bankruptcy, 64 OHIO ST. L.J. 855, 883-94 (2003); Tabb, supra note 49, at 95-99.

190. Tabb, supra note 49, at 97.

191. Howard, supra note 42, at 1048. 
Professor Czarnetzky offers an overarching theory of the discharge which he denominates as the " "entrepreneurial hypothesis." 192 To Professor Czarnetzky, the bankruptcy discharge is available in order to resolve the "tension between freedom of contract and freedom of action in the market." 193 To this end, the bankruptcy discharge is "part of the institutional framework vital to fostering entrepreneurship in the market." 194 Stated differently, the bankruptcy discharge allows the honest individual engaged in business to be freed from the constraints of impossible debt when unexpected and unavoidable business misfortune occurs. ${ }^{195}$ In short, for Professor Czarnetzky, the consumer discharge encourages the individual to act in an entrepreneurial spirit within the institution of the marketplace. ${ }^{196}$ In sum, Professor Czarnetzky concludes that the "gains from entrepreneurship in the form of social improvement and prosperity are larger than the losses to the debtor's creditors from the discharge of his debts." 197

Admittedly, the economic theory for the consumer discharge advanced by Professors Howard and Czarnetzky form a basis for the theory of consumer utility advanced in this Article. The individual consumer debtor, and by extrapolation, the universe of consumer debtors, are benefitted by a discharge that serves to return them to economic productivity as a functioning member of the credit economy. The theory of consumer utility advanced herein, however, accounts for more than just the economic rehabilitation of the individual debtor. It serves to promote not only the financial well-being of the debtor, but the physical, psychological, and familial well-being of the debtor as well. Moreover,

\footnotetext{
192. Czarnetzky, supra note 56, at 397.

193. Id.

194. Id. at 399.

195. Professor Czarnetzky argues thusly:

As presently constituted, the availability of the bankruptcy discharge provides the entrepreneur the assurance that if he acts honestly but fails, he will not be subject to debt servitude and the will of his creditors for some extended period of time. He therefore is much more willing to act entrepreneurially than he would be otherwise. Without the discharge, his concern about the consequences of failure, and his knowledge that failure can befall even the brilliant and diligent entrepreneur, will lead him to be more hesitant, less likely to act entrepreneurially. On the other hand, the entrepreneur knows that if he acts dishonestly or dissolutely, the bankruptcy system will not provide him with a discharge, and he will bear the full brunt of his sins.

196. As Professor Czarnetzky argues: "the entrepreneurial hypothesis provides a justification for the individual discharge that has little to do with the debtor and his individual profile - a subject of much heated debate in the scholarly literature - but rather the institutional environment which best encourages the entrepreneur to act." Id.

197. Id. at 414
} 
and as will be discussed below, recent empirical scholarship has argued that the consumer discharge in its present form does not completely restore a debtor to financial wellness. Thus, the theory of consumer utility offers arguably a broader discharge than that advanced by Professors Howard and Czarnetzky - one that will help address these recent empirical findings. With this background, this Article now turns to developing the theory of discharge based upon consumer utility.

\section{CLASSICAL UTILITARIANISM RECONSIDERED AS A THEORY OF CONSUMER UTILITY}

As many are aware, the utilitarian philosophical movement is generally regarded as having originated with Jeremy Bentham in the early nineteenth century. ${ }^{198}$ While classical British empiricism had been concerned with the nature, scope, and limits of human knowledge, the utilitarian movement engendered by Bentham was a practical affair, premised upon legal and political reform. ${ }^{199}$ "The general idea of utilitarianism is that the right decision is the one that produces the greatest good or utility." 200 And in contrast to deontology, ${ }^{201}$ with its concern for the intrinsic rightness or wrongness of the act itself, utilitarianism is consequentialist by nature, ${ }^{202}$ concerned fundamentally with the outcome of a given act to determine its justness. ${ }^{203}$

198. Frederick Copleston, 3 A History of Philosophy 1 (Doubleday 1966). That said, however, an argument may be made that utilitarian thought began even earlier than Bentham, with ANTHONY A.C. EARL OF SHAFTESBURY, An Inquiry Concerning Virtue or Merit, in Characteristics of Men, MANNERs, Opinions, Times 237 (2004), and FranCis HutCHEsON, $A n$ Inquiry Concerning Moral Good and Evil, in AN INQUIRY INTO THE ORIGINAL OF OUR IDEAS OF BEAUTY AND VIRTUE 180 (3d ed. 1729), wherein Hutcheson stated the principle of utility as follows: "[t]hat Action is best, which procures the greatest Happiness for the greatest Numbers; and that, worst, which, in like manner, occasions Misery." Bentham himself was heavily influenced by David Hume's Treatise of Human Nature and Principles of Morals, in addition to the French Enlightenment philosopher Helvetius. COPLESTON, supra, at 4.

199. Id.

200. Lawrence B. Solum, To Our Children's Children's Children: The Problems of Intergenerational Ethics, 35 LOY. L.A. L. REV. 163, 191 (2001).

201. Deontological theory asserts that "[c]ertain kinds of act are intrinsically right and other kinds intrinsically wrong. The rightness or wrongness of any particular act is thus not... determined by the goodness or badness of its consequences." David McNaughton, Deontological Ethics, in CONCISE RoutledGe ENCYClOPEDIA OF PHILOSOPHY 202 (2000).

202. The theory of consequentialism "assesses the rightness or wrongness of actions in terms of the value of their consequences." David McNaughton, Consequentialism, in CONCISE ROUTLEDGE ENCYCLOPEDIA OF PHILOSOPHY, supra note 201, at 169.

203. See HodgSON, supra note 39, at 1 ("Utilitarian appraisal is appraisal by reference to consequences. The thesis that acts should be so appraised is the common feature of the moral systems which come under the name "utilitarianism."'); Timothy Fuller, Jeremy Bentham and James Mill, in History of Political Philosophy 721 (Leo Strauss \& Joseph Cropsey eds., 3d ed. 1987) 
Bentham conveyed his utilitarian philosophy primarily in his famous work, An Introduction to the Principles of Morals and Legislation, published in 1789. At the outset in his work, Bentham describes the underlying dynamics for his philosophy as follows:

Nature has placed mankind under the governance of two sovereign masters, pain and pleasure. It is for them alone to point out what we ought to do, as well as to determine what we shall do. On the one hand the standard of right and wrong, on the other the chain of causes and effects, are fastened to their throne. They govern us in all we do, in all we say, in all we think: every effort we can make to throw off our subjection, will serve but to demonstrate and confirm it. ${ }^{204}$

As a result of Bentham's view of the human condition being governed by both pain and pleasure, he developed his "principle of utility" to guide not only individual decisions, but also the legislative decisions of government. To Bentham, the principle of utility is that "which approves or disapproves of every action whatsoever, according to the tendency which it appears to have to augment or diminish the happiness of the party whose interest is in question; or, what is the same thing in other words, to promote or to oppose that happiness."205 In operation, Bentham's principle of utility was geared toward his fictitious "community," rather than toward each individual member comprising

("To utilitarians, consequences must be weighed whenever arguments arise among alternative possible courses of action. Whenever individuals permit each other to express opinions, or find they cannot escape them, they must argue the relative merits of differing courses of action with respect to their possible outcomes."); Marco J. Jimenez, The Value of a Promise: A Utilitarian Approach to Contract Law Remedies, 56 UCLA L. REV. 59, 64 (2008) ("It is a rough, but not entirely inaccurate, characterization to say that whereas a consequentialist would focus on the end of a given act to determine whether or not that act is just or unjust, a nonconsequentialist making a similar determination would focus instead on the means used to achieve that end."). See also KwAME ANTHONY APPIAH, THINKING IT THROUGH: AN INTRODUCTION TO CONTEMPORARY PHILOSOPHY 206 (2003) (contrasting consequentialism from deontology); SAMUEL SCHEFFLER, THE REJECTION OF CONSEQUENTIALISM 2 (1994) ("In contrast to consequentialist conceptions, standard deontological views maintain that it is sometimes wrong to do what will produce the best available outcome overall."). As Professor Marco J. Jimenez describes, the "war" between consequentialism and deontology has been raging for more than a century, with "each side [sending] its champion to do battle, and, although bloodied, scarred, and exhausted from the fight, each is still standing, with no clear winner or end in sight." Jimenez, supra, at 59 (footnote omitted). It should, however, be noted that R.G. Frey submits that consequentialism and utilitarianism are distinct, as "[o]ne may be a consequentialist without being a utilitarian, as with ethical egoists, and one may be a utilitarian without being a consequentialist, as with rule-utilitarians and adherents to the different forms of utilitarian generalization, all of whom specifically reject the view that acts are right or wrong solely in virtue of their consequences." R.G. Frey, Introduction: Utilitarianism and Persons, in UTILITY AND RIGHTS, supra note 39, at 5.

204. JEREMy BENTHAM, AN INTRODUCTION TO THE PRINCIPLES OF MORALS AND LEGISLATION 11 (J.H. Burns \& H.L.A. Hart eds., Athlone Press 1978) (1789).

205. Id. at 12 . 
that community. ${ }^{206}$ In other words, public utility was Bentham's primary concern. ${ }^{207}$

With respect to the "community," or general public, Bentham summarized the principle of utility as follows: "[t]he general object which all laws have, or ought to have, in common, is to augment the total happiness of the community; and therefore, in the first place, to exclude, as far as may be, everything that tends to subtract from the happiness . ..."208 Thus, according to utilitarianism, an act is considered just to the extent that it increases pleasure, or happiness, and unjust to the extent that it decreases pleasure, or to the contrary, increases pain. ${ }^{209}$ Stated perhaps more concretely, proper actions, laws or institutions operating pursuant to a utilitarian philosophy "are those which achieve the greatest happiness for the overall community," 210 or the greatest happiness for the greatest number.

Although Bentham produced the principle of utility as a rationale for legislation, ${ }^{211}$ it is no doubt a workable theory that can be adequately applied to specific areas of law. ${ }^{212}$ Nevertheless, while the overarching theory of utilitarianism is easy to reproduce, more circumspect issues need to be raised and addressed before the theory can be adapted and applied to a specific area of the law, and in this instance, bankruptcy law. In addition, the issues to be addressed by their nature also raise the criticisms that have been lodged against utilitarianism during approximately the past two centuries. ${ }^{213}$

\footnotetext{
206. As Bentham explained:

The interest of the community is one of the most general expressions that can occur in the phraseology of morals: no wonder that the meaning of it is often lost. When it has a meaning, it is this. The community is a fictitious body, composed of the individual persons who are considered as constituting as it were its members. The interest of the community then is, what? - the sum of the interests of the several members who compose it.

210. Tibor R. Machan, Some Philosophical Aspects of National Labor Policy, 4 HARV. J.L. \& PUB. POL'Y 67, 129 (1981).

211. RosenBLUM, supra note 207, at 9 .

212. Other areas of the law that have been explained by utilitarian theory include criminal law, contracts, and torts. See Richard A. Posner, Utilitarianism, Economics, and Legal Theory, $8 \mathrm{~J}$. LEgal Stud. 103, 106 (1979). See generally Guyora Binder \& Nicholas J. Smith, Framed: Utilitarianism and Punishment of the Innocent, 32 RUTGERS L.J. 115 (2001) (discussing a utilitarian approach to punishment); Jimenez, supra note 203, at 59 (arguing for a utilitarian approach to contract law).

213. As Peter J. King explains, “[b]ecause he was primarily a reformer, Bentham's philosophy and psychology is simple, crude, and open to all manner of objections and has been lambasted not
} 
The first question a utilitarian-derived theory must face is: What is utility? Or, put differently, what is the good that ought to be maximized by a law or a policy? As noted, Bentham expressed his utility maximand as "happiness" or "pleasure." Bentham identified fourteen "simple pleasures" to which human beings are susceptible: the pleasures of sense, wealth, skill, amity, a good name, power, piety, benevolence, malevolence, memory, imagination, expectation, association, and relief. ${ }^{214}$ These identified "simple pleasures" mean what they mean in ordinary terms, no more and no less. ${ }^{215}$ That said, however, for Bentham "happiness" or "pleasure" is a relativistic concept, and one not dependent upon hedonistic ethics. ${ }^{216}$

Before defining the maximand of the proposed theory, one additional observation of Bentham's philosophy is necessary. Significantly, Bentham did not view the law as immutable. Rather, he recognized that because the consequences of a given policy may change, the moral quality of the policy or law may change as well. As noted by Nancy Rosenblum, to Bentham the act of lawmaking "must be recognized as a continual process in response to diverse and changing desires that require adjustment." ${ }^{217}$ If one accepts this characterization of the mutability of the classic utilitarian theory, then a law that seemed "good" and appropriate at a certain point in time might prove "bad" and inappropriate at some later date. As such, lawmakers and judges must be sensitive to changing social circumstances.

This flexibility regarding utilitarian philosophy's ability to adapt lends credence to adopting a utilitarian approach to the consumer discharge. The promulgation of the 1978 Bankruptcy Code constituted a movement in the evolution of bankruptcy law that was decidedly prodebtor. A reversion back to the creditor-centric Bankruptcy Code began in the early 1990's as the credit industry undertook the efforts described above to convince Congress of widespread debtor abuse, despite the wealth of empirical studies suggesting otherwise. Congress, however,

only by his foes and impartial critics but even by his friends." PETER J. KING, UTILITARIAN JURISPRUDENCE IN AMERICA: THE INFLUENCE OF BENTHAM AND AUSTIN ON AMERICAN LEGAL THOUGHT IN THE NINETEENTH CENTURY 42 (1986).

214. BENTHAM, supra note 204, at 42. Conversely, Bentham identified twelve "simple pains," as follows: the pains of privation, the pains of the senses; the pains of awkwardness, the pains of enmity, the pains of an ill name, the pains of piety, the pains of benevolence, the pains of malevolence, the pains of the memory, the pains of the imagination, the pains of expectation, and the pains dependent on association. Id. at 33-34.

215. COPLESTON, supra note 198 , at 8.

216. Id.; see also DANiEl M. HAUSMAN \& Michael S. McPherson, ECONOMiC ANALYSiS, MORAl PhILOSOPHY, AND PUBLIC POLICY 100-01 (2006).

217. ROSENBLUM, supra note 207 , at 9. 
took the bait and enacted BAPCPA. Simply put, another period in the evolution of bankruptcy law must now take place, one that accounts for the economic realities facing the nation's economy.

A theory of consumer discharge premised upon principles of utilitarianism can accomplish this task. More specifically, the theory of consumer utility serves both as an underlying justification of why bankruptcy law provides for a discharge as well as a corrective response to the misguided enactment of BAPCPA and the current economic recession. Further, the maximand to be seized upon is one that relieves the consumer debtor of overwhelming indebtedness and lifts him or her from the pit of economic suffering, and all of its resulting consequences. Stated in Benthamite terms, a principle of consumer utility would aim to promote the overall well-being of the community of debtors who file for bankruptcy protection each year, financially, psychologically, and physically, while disapproving of or seeking to diminish the "misery" associated with BAPCPA.

As Professor R.G. Frey has observed, "[a]n abstract formulation of the principle, such as '[a]lways maximize net utility' cannot be applied in the absence of some interpretation of utility, since one would not know what to maximize." 218 That said, "[t]he term 'utility' ... is a blanket term, to be filled in by whatever standard of goodness is adopted. The principle, moreover, is a maximizing one, enjoining its adherents to maximize in the world that which their value-theory is focused around, and it is applied directly to individual acts." 219

As demonstrated previously, with the exception of BAPCPA, bankruptcy law in the United States since 1841 and its accompanying interpretation by the courts has been concerned with the financial wellbeing of the downtrodden debtor and with his or her position in society. This observation is unassailable. Given this reflection, it is certainly not a radical proposition to advance a theory for the consumer discharge that is primarily focused upon the collective body of debtors who file for bankruptcy relief each year, and less concerned with the interests of his or her creditors. This is a normative choice indeed, but one that fits comfortably within the existing scholarly and practical paradigm of the bankruptcy system. That said, one may also construe BAPCPA as a normative choice. To be sure, expanding the scope of the consumer discharge may decrease the utility of creditors by limiting their financial recoveries due to the happenstance of bankruptcy. This may, in turn,

218. Frey, supra note 203, at 5 .

219. Id. 
cause negative externalities as a result of the consumer-utility theory advanced herein, namely, increased borrowing rates and the reduction of available credit in the future. Arguments over such negative externalities have been made in the past, but the concerns have not played out, particularly since the availability of credit has only expanded during the past several decades.

The existing scholarly literature on the justification for the consumer discharge raises defensible and worthwhile arguments. But what has not been accomplished is the advancement of an overarching theory justifying the discharge that can embrace and account for all of the concerns of the individual debtor, and by extension, the community of debtors. Thus, this Article proposes a metatheory of consumer utility to justify the discharge in modern bankruptcy law.

As stated, the "good" to be maximized by a theory of consumer utility is the promotion of the debtor's holistic well-being, and by extrapolation, the community of debtors who file for bankruptcy protection each year. To begin, the prospect of a discharge for those inundated with debt provides an incentive to comport with the requirements of the federal bankruptcy laws, to be forthcoming and candid in the disclosure of their finances in the requisite bankruptcy petition and schedules, and to assist the trustee in identifying and collecting non-exempt assets in the Chapter 7 process. ${ }^{220}$ This accounts for the debtor cooperation theory of the consumer discharge as advanced by Professor Tabb and others. ${ }^{221}$

A theory premised upon collective consumer utility, however, provides more - the overall welfare of a debtor can be further maximized beyond the "carrot" incentive of forthright participation. A theory of consumer utility also satisfactorily accounts for the theories of discharge advanced by Professor Jackson. To the extent one is comfortable with

220. Knowingly and fraudulently submitting false information may result in the denial of a Chapter 7 discharge under $\S 727(a)(4)$ and may constitute a crime pursuant to 18 U.S.C. $\S 152$. See 11 U.S.C. § 727(a)(4) (2006); see also 18 U.S.C. § 152 (2006). Furthermore, § 542(a) of the Code requires that any entity or person in possession of property of the bankruptcy estate must turn over such property to the trustee. Section 542(a) of the Code provides as follows:

Except as provided in subsection (c) or (d) of this section, an entity, other than a custodian, in possession, custody, or control, during the case, of property that the trustee may use, sell, or lease under section 363 of this title, or that the debtor may exempt under section 522 of this title, shall deliver to the trustee, and account for, such property or the value of such property, unless such property is of inconsequential value or benefit to the estate.

11 U.S.C. § 542(a) (2006).

221. See generally Tabb, supra note 49 , at 90 (stating "creditors essentially forego the possibility of postbankruptcy recovery tomorrow in the hope of reaping larger bankruptcy dividends today"). 
accepting paternalistic attitudes towards debtors in general, a utilitarian theory of consumer discharge maximizes the overall welfare of debtors by protecting consumers from their irresistible impulses to incur indebtedness, even when doing so is not in their best interests.

More significantly, the availability of a consumer discharge maximizes overall well-being because it provides honest but unfortunate debtors with a safety-net if they incur debt that later proves beyond their ability to repay due to the underestimation of risk or the overestimation of future success, or both. Importantly, the theory of consumer utility advanced herein also accounts for the criticisms of Professor Jackson's theories lodged by Professor Tabb. As will be discussed below, the consumer-utility theory calls for the abandonment of the exceptions to discharge currently contained with $\S 523$ of the Code. ${ }^{222}$ By abolishing $\S$ 523 in whole cloth, save for the exception for debts arising from domestic support obligations or equitable distribution proceedings, the discharge can rectify problems of impulse control and incomplete heuristics.

Further, a broader discharge premised upon the collective utility of debtors furthers the successful reintegration of debtors to economic productivity, in accordance with Professor Howard's theory of economic rehabilitation. Overall economic health improves by shifting people from a state of less productivity to a state of higher productivity. ${ }^{223}$ As Professor Howard has offered, the discharge enables the debtor to "resume economic participation in the open credit economy." 224 That is, consumers who are freed of constricting debt obligations can take that portion of their incomes once dedicated to attempting to fruitlessly repay their creditors and place this income into the stream of economic commerce. Moreover, freed of this indebtedness, debtors will have every incentive to resume productivity, rather than contemplate idleness if working only produces a return for the creditors.

A theory of consumer utility incorporates Professor Howard's economic theory of discharge, but it too provides more, namely a broader discharge, largely in response to recent scholarly contributions suggesting that the discharge in its current state does not go far enough in providing a fresh start to the debtor. In the first of such articles, Professor Jean Braucher suggests that " $[t]$ he idea of a 'fresh start' is part of the mythology of consumer bankruptcy but perhaps not the reality for

222. See generally 11 U.S.C. § 523(a) (2006).

223. MCKIBBEN, supra note 10 , at 110 .

224. Howard, supra note 42, at 1062. 
most of those who file." ${ }^{225}$ Based upon her suspicion in this regard, Professor Braucher noted the need for a longitudinal study to be conducted to determine if debtors are, on average, better off financially "one, three, five, or ten years after a bankruptcy filing, whether in Chapter 7 or Chapter 13."226 Following on the heels of Professor Braucher's call, Professors Katherine Porter and Deborah Thorne conducted an empirical study on this issue and concluded that the fresh start is an "incomplete tool to rehabilitate those in financial distress." 227 The results of the empirical study conducted by Professors Porter and Thorne are summarized in this way:

[W]hile bankruptcy appears to help a majority of families to obtain a sustainable fresh start, many former debtors continue to experience financial hardship that is as bad as or worse than the distress that initially triggered their bankruptcy filings. For many families, the fresh start either failed to materialize or dissipated within one year of the discharge of their debts. Data that we gathered on postbankruptcy financial management buttressed this finding: One year after bankruptcy, one in four families reported that paying their expenses was an ongoing struggle. For these families, the promise of a better life was a theoretical hope, distant from the reality of their continuing financial difficulties.

The findings by Professors Porter and Thorne are very significant, and many of the questions raised by their research are beyond the scope of this Article. For example, Professors Porter and Thorne suggest that in order to achieve a fresh start in the truest sense, policy changes in the nation's unemployment system and medical care system may need to be made. $^{229}$ While a theory of discharge grounded in utility may not be the precise panacea called for by Professors Porter and Thorne, the broader discharge advocated by the theory of consumer utility certainly complements their work. That is, a more generous discharge, one that relieves categories of indebtedness that cannot be currently discharged through the bankruptcy process, may help some of the debtors identified by Professors Porter and Thorne to realize the otherwise elusive fresh start. $^{230}$

\footnotetext{
225. Braucher, supra note 93, at 1070.

226. Id. at 1085.

227. Porter \& Thorne, supra note 44 , at 67.

228. Id. at $69-70$ (footnote omitted).

229. Id. at 99-109.

230. Another recent study on this issue was released in 2008. See Zagorsky \& Lupica, supra note 44 , at 283 (finding that a Chapter 7 discharge does not result in a fresh start in the short-term because it takes years for filers to catch up to non-filers in the key areas of financial stability).
} 
The theory of consumer utility also accounts for the humanitarian theory of discharge put forth by Professors Gross and Flint. That is to say relieving a debtor of overwhelming indebtedness returns one's sense of self-worth and dignity in one's personal and economic life. Assuming that the stigma of having filed for bankruptcy (both self-imposed and externally-imposed by society in general) does not outweigh the lack of dignity of having become hopelessly mired in debt, then a theory of consumer utility also encompasses a return to human dignity for the honest but unfortunate debtor.

More importantly, though, the theory of consumer utility addresses the questions raised by Professor Tabb with respect to the humanitarian theory. First, the creditor's consent to the "forgiveness scheme" need not be overtly considered in the equation. ${ }^{231}$ Without a doubt, creditors will not consent to a discharge of indebtedness ex ante for the purposes of promoting good citizenship. But their consent is already implied in the consumer lending system because the cost of credit is higher overall as a result of the ability of a debtor to seek shelter through the bankruptcy process. While no empirical study has been conducted to determine how much higher the cost of credit is as a result of this condition, it is arguably negligible when the desired outcome is to restore one's humanity. With respect to Professor Tabb's second concern regarding a humanitarian approach, the debtor does in fact need to prove deserving in order to take advantage of the "discharge gift.",32 As will be stated below, the consumer-utility theory provides that only the honest, forthcoming debtor can take advantage of the broadened discharge.

Although a theory of consumer utility accounts for and encompasses all existing scholarly theories relating to the discharge, it satisfies other concerns many debtors face. Accordingly, the theory of consumer utility justifies the broader discharge because it helps alleviate the psychological, familial, and physical trauma and strain experienced by many debtors buried with insurmountable debt. To date, no substantial empirical study has been conducted in American legal literature addressing the effects of debt on a debtor's psychological and familial well-being. ${ }^{233}$

231. Tabb, supra note 49 , at 97.

232. Id.

233. It has, however, been mentioned in passing. See, e.g., Braucher, supra note 93, at 1077-78 ("Also, there is reason to believe that this risk pool suffers from anxiety-related psychological and social problems, including family problems, health problems, and work problems."); Porter \& Thorne, supra note 44, at 74 ("Similarly, the law does not explicitly effectuate the psychological and emotional relief that families should experience from filing bankruptcy."); Stein, supra note 99, at 624 ("People tend to experience emotional and physical problems as a result of carrying debt."). 
However, a recent study conducted by Christopher G. Davis and Janet Mantler with the Centre for Research on Stress, Coping, and WellBeing at Carleton University in Canada provides some disturbing insights into the conditions faced by many debtors. ${ }^{234}$ As the authors' findings suggest, financial stress is associated with a higher incidence of mental and physical health problems. ${ }^{235}$ Individuals under serious economic strain are likely to suffer from headaches, stomachaches, and insomnia. ${ }^{236}$ Moreover, for the individual, chronic financial strain is associated with increased alcohol consumption and even suicide. ${ }^{237}$ And, as perhaps expected, Davis and Mantler report that financial strain can oftentimes lead to clinical depression, which serves to motivationally cripple the individual. ${ }^{238}$

In addition to the individualistic effects of excessive debt, Davis and Mantler suggest that "as financial stress increase[s], couples... [are] more likely to break up." 239 Indeed, Davis and Mantler report that in some cases, the pressure of over-indebtedness often leads to an increase in arguments between the partners as well as general marital dissatisfaction. ${ }^{240}$ The effects of financial distress on couples also trickle down to children. According to Davis and Mantler, "[s]everal studies now show that parents (especially fathers) who are experiencing financial stress are less responsive to their children's needs, are less consistent in their parenting, and are more inconsistent in their discipline of children."241 The effects on children can be great:

234. See generally Christopher G. DAvis \& JANet MANTler, The CONSEQuences of FINANCIAL STRESS FOR INDIVIDUALS, FAMILIES, AND SOCIETY (2004), available at http://www.doylegroup.ca/personal/reports/financial_distress_DSI.pdf (discussing how financial stress affects homes and communities).

235. Id. at $9-10$.

236. $I d$. at 10 .

237. Id. at $9-12$.

238. Id. at 13. As Davis and Mantler state:

Depression is not simply sadness or laziness. Depression is a serious mental disorder that not only robs people of their joy of life, but it also has significant motivational, cognitive, and behavioural consequences. People who are depressed become hopelessly mired in a worldview where it seems that nothing they can do will change anything; where getting out of bed in the morning is the most difficult thing to do; and where one expects the worst and is not surprised when bad things keep happening. Research indicates that people who are depressed are motivationally crippled (i.e., they have no energy to try), Id. and they see the world through a pessimistic lens.

239. Id. at 10

240. Id. at 14 .

241. Id. at 16 . 
Children of financially stressed parents tend to be more prone to mental health problems, depression, loneliness, and are more emotionally sensitive. They are less sociable and more distrustful, and are more likely to feel excluded by their peers, especially if they are girls. Boys of financially stressed parents are likely to exhibit low selfesteem, to show behaviour problems in school, and be susceptible to negative peer pressure and alcohol and drug problems. Financial stress is related to poorer academic performance in both boys and girls. ${ }^{24}$

A theory of discharge based upon consumer utility would take these serious effects of financial strain into account when interpreting the scope of the bankruptcy discharge, particularly because the external costs to society are so significant. While the credit industry proponents of BAPCPA liked to tout figures over how much the bankruptcy system costs the nation each year, they never considered the external costs to society in the form of a sick or chronically depressed employee, a family in distress, or a child experimenting with illicit drugs. Although no empirical study on this issue has been conducted to date, the associated external costs of financial strain on the medical care and social services systems could be potentially quite high.

The utility principle advanced by Bentham, interpreted as a public welfare standard for the community of debtors as it is here, "is fundamental to a work on legislation because it provides a useful standard of value." ${ }^{243}$ This observation leads to the second question that a utilitarian-derived theory must address; namely, how does one measure the benefit to society by maximizing the utility value? In other words, what does the greatest good for the greatest number mean? For Bentham, measuring the utility to society was accomplished through a felicific calculus. First, the value of a pleasure or pain to the community would be greater or less according to seven dimensions: its intensity, its duration, its certainty or uncertainty, its propinquity or remoteness, its fecundity, its purity, and its extent. ${ }^{244}$ After one assigns a value to the tendency of an act to produce pleasure or pain, Bentham instructs to "[s]um up all the values of all the pleasures on the one side, and those of all the pains on the other."245 If, after applying this mathematical equation, the balance of pleasure versus pain tips in favor of pleasure,

242. Id. at 18 (citations omitted).

243. Binder \& Smith, supra note 212 , at 168.

244. BENTHAM, supra note 204, at 38-39.

245. Id. at 40 . 
then the act has the tendency to produce good results for the community. ${ }^{246}$

Consequently, for Bentham the aim of legislation is to maximize the happiness or pleasure of the collective community, and applied here, the community of consumer debtors who file for bankruptcy relief. However, as may be obvious, one of the strongest critiques of utilitarianism is the impossibility of applying Bentham's felicific calculus with any degree of accuracy. Where would one even begin? Indeed, Bentham himself recognized the shortcomings of his own theory:

It is not to be expected that this process should be strictly pursued previously to every moral judgment, or to every legislative or judicial operation. It may, however, be always kept in view: and as near as the process actually pursued on these occasions approaches to it, so near will such process approach to the character of an exact one. ${ }^{247}$

This critique of utilitarianism is arguably impossible to resolve, and this Article does not pretend to offer a proposed resolution that has otherwise escaped philosophers, economists, historians, and legal scholars over the past two centuries. That said, however, and as stated at the outset, the principle of utility can operate as a useful standard for judging the efficacy of the consumer-bankruptcy system as a whole, and as a normative statement of the role the bankruptcy system should play in the lives of unfortunately downtrodden debtors.

\section{THE CONSUMER UTILITY THEORY AS APPLIED TO THE CURRENT STATE OF BANKRUPTCY LAW}

In the historical progression of bankruptcy law in the United States, there has been a traditional vacillation between legislation that can be characterized as "anti-debtor" and legislation that is conversely characterized as "pro-debtor." Many observers would agree that the 1978 Bankruptcy Code can be viewed as an example of "pro-debtor" legislation. To the contrary, the amendments to the Code through BAPCPA can only be viewed as anti-debtor legislation. Because of the current economic conditions and the financial reality of most consumer debtors - a reality that is inapposite to the one Congress envisioned when it enacted BAPCPA - it is time for the nation's bankruptcy laws to shift once again in the direction of favoring debtors. Doing so will require a 
two-pronged approach. First, bankruptcy courts must start interpreting most aspects of the Code in a way that promotes utility for the community of consumer debtors. Second, Congress must act to repeal the changes in the Code occasioned by BAPCPA that threaten a true fresh start. While the latter proposal may be an impossible goal, Congress's recent consideration of amending the Code to permit debtors to modify home mortgages does provide a glimmer of hope.

The question of how broadly or narrowly a consumer debtor's discharge should be construed is unquestionably an issue of public policy. ${ }^{248}$ In proposing such a solution, it is virtually impossible to do so without first recognizing the inherent tension between the interests of creditors seeking repayment and the interests of debtors in escaping overwhelming indebtedness. As a normative matter, the inquiry devolves into whether society should favor debtors as a collective group or whether society should protect the contractual rights of creditors. The theory of consumer utility advanced herein unapologetically prefers the community of debtors.

Tellingly, the prospect of applying a utilitarian approach to the nation's bankruptcy laws was implicitly, though not overtly, set forth as early as 1919 by commentator F. Regis Noel, who stated as follows:

This mental condition of a member of society brings to it no benefit. On the contrary, society must be seriously injured by the presence of unproductive or discontented members, who through idleness or vicious habits may eventually become public charges. If the laws of bankruptcies were based on the legal rights of individuals, there would be no warrant for the discharge of debtors from the payment of their debts as long as they lived, or their estates would continue to exist. But public policy makes it expedient that insolvent debtors, instead of being forever entangled by obligations as enduring as the task of Sisyphus, shall be given a fresh start in life under the benevolent influence of the ordinary incentives to industry and enterprise .... On the other hand, this benign policy must not be permitted to foster greater evils than unrelieved insolvency produces. The mode of relief should be elastic and graduated according to the comparative merits of the conduct of the debtors and the circumstances which led to their insolvency. ${ }^{249}$

In what ways, then, can a theory of consumer utility find expression in the Code or in proposals for bankruptcy reform?

248. See Adam J. Hirsch, Inheritance and Bankruptcy: The Meaning of the "Fresh Start," 45 HASTINGS L.J. 174, 197-98 (1994) (raising this issue in the context of $\S 541(\mathrm{a})(5)$ of the Code).

249. NOEL, supra note 60, at 188. 
The first proposal for reform calls upon Congress to repeal $\S 109(\mathrm{~h})$ of the Code, added by BAPCPA. In sum, $\S 109(\mathrm{~h})$ establishes that an individual is ineligible for bankruptcy relief unless that person has received "during the 180-day period preceding" the date of the petition an individual credit-counseling session conducted by an approved nonprofit budget and credit-counseling agency. ${ }^{250}$ The required briefing, which can take place by telephone or on the Internet and be accomplished in approximately thirty minutes, must outline the opportunities for credit counseling and assist the individual "in performing a related budget analysis. ${ }^{251}$ By revising the Code in this manner, Congress has made its general policy choice known that debtors should not seek to resort to the bankruptcy process in the first instance, and instead must seek alternative methods for dealing with their financial problems prior to seeking bankruptcy relief. ${ }^{252}$ As one court has noted, "[t]he effect of this legislation is that bankruptcy is a remedy of last resort for the honest but unfortunate debtor." 253

While debtor education may be a laudable goal, to date $\S 109(\mathrm{~h})$ has served to ensnare many debtors who have not complied with the creditcounseling requirement. As the typical consumer debtor's insolvency becomes exacerbated to the point where the individual affirmatively decides to seek bankruptcy relief, the prospective debtor has no idea what the law requires. The end result is that the honest but unfortunate debtor is denied bankruptcy relief when its need is most crucial. For instance, many debtors trying to stave off an impending foreclosure sale attempt to negotiate with the mortgage lender up until the time of the foreclosure sale. If such negotiations prove fruitless, a debtor will file a bankruptcy petition at the eleventh hour in order to stop the commencement of the foreclosure sale and invoke the automatic stay provided by $\S 362$ of the Code. ${ }^{254}$ Should the debtor fail to comply with $\S 109(\mathrm{~h})$, a court will either dismiss or strike the bankruptcy petition. ${ }^{255}$ In either case, no automatic stay applies and the debtor remains in jeopardy of losing his or her home. Moreover, by the time the typical debtor decides to resort to the bankruptcy process - a decision usually not made lightly and not until the pressure from creditor collection

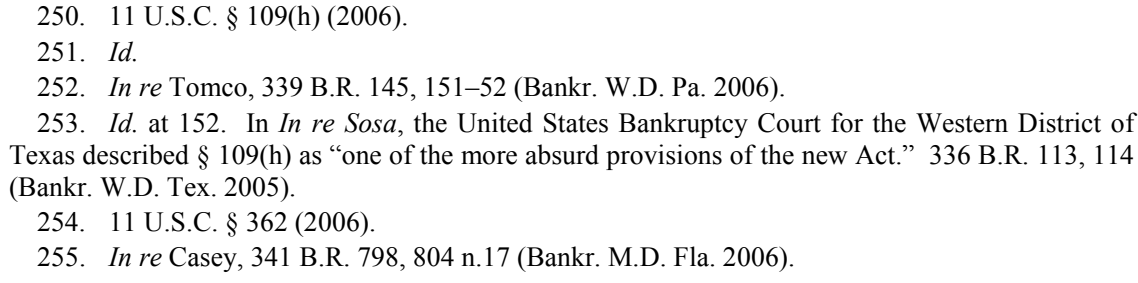


efforts proves unbearable - it is far too late for the vast majority to benefit from a thirty-minute credit counseling session. ${ }^{256}$

The second method by which the theory of consumer utility can be furthered is for Congress to repeal the means test contained in $\S 707(\mathrm{~b})$ in Chapter 7 cases and incorporated in Chapter 13 cases by virtue of $\S$ 1325(b) of the Code. ${ }^{257}$ Prior to the enactment of BAPCPA, former $\S$ 707(b) provided that a court may dismiss an individual debtor's Chapter 7 case if the debts were primarily consumer debts and the granting of relief would constitute a "substantial abuse" of the Chapter 7 process. ${ }^{258}$ Moreover, former $\S 707$ (b) specifically included a provision stating a presumption in favor of granting the debtor the relief requested in filing for Chapter 7. ${ }^{259}$ The former version of the Code did not define the term "substantial abuse." Instead, it was for the bankruptcy judges to exercise their discretion on a case-by-case basis to determine whether the debtor was committing a substantial abuse of the Chapter 7 process. To that end, the majority of courts focused on the totality of circumstances "in an attempt to identify whether the debtor [was] not in need of Chapter 7 relief and [was] merely seeking an advantage over creditors."260 Prior to BAPCPA, judges would deny Chapter 7 relief to those debtors "whose pleadings in the form of the petition, schedules, statement of affairs and statement of income and expenses fail to reflect a need for the relief being sought because they do not reflect that the debtor is now suffering or will suffer in the near future from any meaningful economic hardship. ${ }^{261}$

Other than the rhetoric of consumer abuse spewed by the credit industry and accepted as gospel by Congress, no studies exist suggesting that the nation's bankruptcy judges were ineffective in policing abusive debtors. In other words, no empirical studies exist arguing that bankruptcy judges could not accurately exercise their collective discretion in examining the totality of a particular debtor's economic circumstances. And given the empirical research conducted by Professor Warren and others, no such study would exist because widespread abuse was never a reality of the bankruptcy-law system.

\footnotetext{
256. Sean C. Currie, The Multiple Purposes of Bankruptcy: Restoring Bankruptcy's Social Insurance Function after BAPCPA, 7 DEPAUL BUS. \& COM. L.J. 241, 256 (2009).

257. See $\S 707(b), 1325(b)$.

258. § 707(b) (applying to cases filed before October 17, 2005).

259. Id. (applying to cases filed before October 17, 2005).

260. 6 COLLIER ON BANKRUPTCY $9707.04[4]$ (15th ed. rev. 2007); see also Kornfield v. Schwartz (In re Kornfield), 164 F.3d 778, 783 (2d Cir. 1999) (adopting a totality of the circumstances standard).

261. In re Edwards, 50 B.R. 933, 936 (Bankr. S.D.N.Y. 1985).
} 
Not only have the empirical studies noted in this Article established that the $\S 707$ (b) means test fails to capture many, if any, high-income debtors attempting to game the system, ${ }^{262}$ but for those tens of thousands of debtors each year who manage to have an extra $\$ 150$ in their pockets each month, these debtors are forced into Chapter 13 repayment plans or denied access to the bankruptcy system. Even if Congress were so noble as to let these debtors retain their last $\$ 150$, it still would not shelter them and their families should another unexpected event - even as seemingly innocuous as a needed car repair-befall them. However difficult it may be to overcome the politics backing the current law, the means test of $\S$ 707(b) and incorporated in $\S$ 1325(b) must be repealed, and the "substantial abuse" test returned as it existed prior to BAPCPA.

Further, if - as the recent studies by Professors Porter, Thorne, Braucher, Zagorsky, and Lupica suggest - the current iteration of the Code does not provide debtors with enough of a fresh start so as to return them to a state of sustainability for themselves and their families, then more should be done. In order to effectuate the theory of consumer utility advanced herein, Congress should drastically revise $\S 523$ of the Code and remove most of the debts currently excepted from discharge upon successful challenge by a creditor. Section 523 currently provides for nineteen different categories of debts potentially excepted from the consumer discharge. ${ }^{263}$ Congress should repeal all of these categories with the exceptions of $\S 523(\mathrm{a})(2),(\mathrm{a})(5)$, (a)(8), and (a)(15). ${ }^{264}$

As noted, § 523(a)(2) implicates credit-card debt under the implied representation theory developed by the courts. Because credit-card debt increasingly comprises a greater percentage of the typical debtor's financial obligations, bankruptcy courts should eradicate the implied representation theory in response to credit-card lenders seeking to have their debts declared non-dischargeable. In other words, § 523(a)(2) should be interpreted in a manner that does not encompass voluntary extensions of credit through a charge card. Under this proposal, then, no reason for $\S 523(\mathrm{a})(2)(\mathrm{C})$ would exist, and it too should be repealed. That said, however, because the discharge should be available only to the

262. Critiques of the means test already abound in the scholarly literature regarding the problems inherent in its application and in the potential for high-income debtors to abuse the test itself. See, e.g., Braucher, supra note 100, at 1295; Tabb, supra note 32, at 1 .

263. $\S \S 523(\mathrm{a})(1)-(19)$.

264. The exceptions to discharge contained within $\S 523(a)(5)$ and (a)(15), namely, for debts arising from a domestic-support obligation or incurred during a divorce proceeding, should remain nondischargeable primarily because of the fear of having needy former spouses and children becoming wards of the state and relying upon social-welfare programs. Doing otherwise would cut against any discharge premised upon notions of utility. See § 523(a)(5), (a)(15). 
honest, forthright debtor, $\S 523(\mathrm{a})(2)(\mathrm{A})$ and (B) is still needed. Thus, if a debtor obtains an extension of credit through common law fraud, proven with the requisite mental state, then the debt should be nondischargeable, even under a theory premised upon utility.

In the near future, it is expected that college graduates will default on educational loans in ever-increasing numbers, particularly due to the skyrocketing costs of secondary education and the stagnant opportunities in the labor market. As a result of the current economic times, college students graduating during the recession will likely suffer lower wages for a decade or longer. ${ }^{265}$ To promote the well-being of these individuals and ensure their continued economic production in society, $\S 523(\mathrm{a})(8)$ should be amended to provide for the dischargeability of both government and private educational-loan debt after some time period (e.g., five years) with a good-faith attempt to repay the debt. ${ }^{266}$ If a creditor challenged the dischargeability of educational loans based upon a particular debtor's current economic situation and future prospects of financial success, then a court exercising its discretion under a totality of the circumstances standard can determine whether it would be appropriate to discharge the educational loans on a case-by-case basis. Indeed, as Professor Howard noted more than two decades ago, the enactment of $\S 523(\mathrm{a})(8)$ was "not a legislative response to a statistically significant problem."267 The same argument can be restated today with a certain degree of comfort.

The most prevailing theme in bankruptcy law jurisprudence for the past three centuries is that refuge in bankruptcy should be available only to the honest but unfortunate debtor and not to debtors who have defrauded their creditors or who have failed to cooperate in the bankruptcy process. ${ }^{268}$ This ideal should not be disturbed. Nonetheless, more needs to be accomplished under bankruptcy law to promote the overall well-being of the class of debtors who find themselves

265. Sara Murray, The Curse of the Class of 2009, WaLl ST. J., May 9, 2009, at A1. This assertion is primarily based upon a study conducted by Lisa Kahn, an economist at the Yale School of Management. Id. The study found that "for each percentage-point increase in the unemployment rate, those with the misfortune to graduate during [a] recession earned $7 \%$ to $8 \%$ less in their first year out than comparable workers who graduated in better times." Id. Moreover, this effect persisted over many years, "with recession-era grads earning $4 \%$ to $5 \%$ less by their 12 th year out of college, and $2 \%$ less by their 18 th year out." Id. at A1, A11.

266. This is not the first attempt to prompt Congress to revise $\S 523(\mathrm{a})(8)$. More than twenty years ago, Professor Margaret Howard advocated for the dischargeability of student loans so long as the debtor did not incur the obligation with the intention of filing for bankruptcy relief rather than repaying the loan. Howard, supra note 42, at 1087.

267. Id.

268. See Local Loan Co. v. Hunt, 292 U.S. 234, 244 (1934). 
overwhelmed by inescapable debt. A broader discharge than currently exists will help many debtors, particularly those with middle incomes, large credit-card debts, or high educational loans. To be sure, the more generous discharge called for by the theory of consumer utility will certainly have its detractors, a subject to which this Article now turns.

\section{VIII.OBJECTIONS CONSIDERED}

Aside from the critiques of the theory posed herein that are endemic to classical utilitarian philosophy, there are other potential objections to expanding or liberalizing the discharge as it currently exists.

\section{A. The Problem of Moral Hazard}

Perhaps the most immediate objection to a utilitarian-derived theory of consumer discharge is the possibility of creating a moral hazard problem. Moral hazard "refers to the tendency for insurance against loss to reduce incentives to prevent or minimize the cost of loss."269 Stated differently, moral hazard is premised on the notion that individuals are more likely to take risks if they are insured against the consequences of their actions. Applied to the dynamics of consumer debt, if bankruptcy law is liberalized to provide a greater discharge of indebtedness, consumers will be incentivized to incur greater amounts of unnecessary debt with the knowledge that filing a Chapter 7 petition will relieve them of that debt, assuming compliance with $\S 727$ of the Code.

Taken to its logical conclusion, liberalization of bankruptcy law may well lead to increased bankruptcy filings. ${ }^{270}$ Indeed, even financially solvent debtors will be incentivized to take greater risks in their investment decisions because the ramifications of default can be corrected by filing a bankruptcy petition that assures the debts will be discharged. ${ }^{271}$ As Professor Jason J. Kilborn has suggested, this may not be the desired message to communicate to the public regarding "financial responsibility and a trade-off of burdens for benefits." ${ }^{272}$ Admittedly, completely eliminating the potential moral-hazard problem is perhaps an impossible task. Nevertheless, four distinct observations might assuage those concerned about moral hazard.

269. Tom Baker, On the Genealogy of Moral Hazard, 75 Tex. L. Rev. 237, 239 (1996).

270. Buckley \& Brinig, supra note 91, at 194.

271. Id.

272. Kilborn, supra note 189 , at 884. 
First, the argument of moral hazard is premised upon debtors possessing information about the bankruptcy process and the ability to discharge debt. While a debtor might gain this knowledge after consulting with an attorney, he or she might not have any sophisticated knowledge of how the bankruptcy process works. The debtor would thus be unaware of the available discharge "insurance" ex ante. Although not based on any empirical study, it is still relatively safe to presume that the average consumer debtor does not have any specialized knowledge of the intricate workings of bankruptcy law.

Second, although some individuals might abuse the bankruptcy system if a generous discharge exists, the number would be small compared to the debtors resorting to bankruptcy for legitimate purposes. Third, while the problem of moral hazard is real, the economic premise underlying moral hazard ignores "the larger social benefits of insurance, what economists would call 'positive externalities.",273 In other words, the net societal gain from a liberal discharge may offset the external costs to society as a whole. Fourth, concerns about moral hazard are arguably alleviated by the social stigma attached to filing for bankruptcy relief. Even if a virtually complete discharge could be had, people would remain reticent to file for bankruptcy protection based upon their internal beliefs about how family, friends, and society in general will perceive them. Although there is current academic discussion regarding whether a social stigma to bankruptcy still exists, ${ }^{274}$ it unquestionably remains, and will remain, a disincentive to seeking bankruptcy protection.

\section{B. The Moral Obligation to Honor Contracts}

As a second objection to the theory of consumer discharge advanced herein, one can argue that permitting a debtor to, in effect, breach and then escape his or her financial obligations offends the moral norm of honoring one's contracts. ${ }^{275}$ As one scholar has noted, the moral obligation to respect contractual promises "is a virtually universal ethical precept." ${ }^{276}$ Indeed, such an objection traces its roots to the historical

273. Baker, supra note 269 , at 243.

274. See, e.g., Rafael Efrat, Bankruptcy Stigma: Plausible Causes for Shifting Norms, 22 EMORY BANKR. DeV. J. 481, 485-88 (2006); Rafael Efrat, The Evolution of Bankruptcy Stigma, 7 THEORETICAL INQUiRIES L. 365, 380-85 (2006); Edith H. Jones \& Todd J. Zywicki, It's Time for Means-Testing, 1999 BYU L. REV. 177, 215-21 (1999); Lawless et al., supra note 9, at 383-85; Teresa A. Sullivan et al., Less Stigma or More Financial Distress: An Empirical Analysis of the Extraordinary Increase in Bankruptcy Filings, 59 STAN. L. REV. 213, 233-47 (2006).

275. See, e.g., Hirsch, supra note 248, at 223-29.

276. Hallinan, supra note 23, at 140. 
treatment of debtors as thieves and criminals. ${ }^{277}$ Although a moral obligation to honor contractual promises has arguably fallen out of favor over the past few decades, ${ }^{278}$ it remains a viable argument nonetheless.

Two counterarguments cut against the power of the moral obligation concept. First, the bankruptcy process already permits both individual and corporate debtors to reject and breach contracts under various provisions of the Code, such as $\S 365$ and $\S 1113 .{ }^{279}$ Second, a moral obligation argument presupposes an arms-length dynamic between consumer and lender in the credit transaction. This supposition is incorrect - on the contrary, parity generally does not exist between borrower and lender. Therefore, one can argue that precisely because of the great disparity in power between lender and debtor, together with the complexities in the consumer-credit marketplace, creditors have a moral obligation not to lend aggressively and improvidently. ${ }^{280}$ If they do so, as they have done collectively in the recent past, creditors should bear the financial consequences and moral responsibility when their debtors default. $^{281}$

\section{The Transfer of Costs and Risk Allocation}

Other scholars have argued that society is better off if creditors are paid and debtors are required to satisfy their financial obligations. ${ }^{282}$ This is so because the losses to creditors through a discharge are borne by other borrowers in the form of higher interest rates and administrative charges in the extension of credit. ${ }^{283}$ Moreover, institutional lenders may also suffer losses of equity because of numerous debtors failing to pay back their debt obligations. ${ }^{284}$ Not only are the losses caused by defaulting debtors internalized by other borrowers, but the availability of credit may be reduced if the costs of risk taking increases for lenders. ${ }^{285}$ Thus, from an economic standpoint, an even broader discharge than what

277. Hirsch, supra note 248, at 226.

278. Id. at 229 ("At any rate, other theorists today downplay or even deny the debtor's moral obligation to lenders in connection with the modern market for consumer credit.").

279. See generally 11 U.S.C. $\S \S 365,1113$ (2006) (discussing the right to assume or reject executory contracts, unexpired leases and collective bargaining agreements, respectively).

280. Hirsch, supra note 248, at 229 n.177.

281. See id. This is not the first time this argument has been raised. See, e.g., John D. Ayer, How to Think About Bankruptcy Ethics, 60 AM. BANKR. L.J. 355, 369 (1986); Vern Countryman, Improvident Credit Extension: A New Legal Concept Aborning?, 27 ME. L. REV. 1, 17 (1975).

282. See, e.g., Hirsch, supra note 248, at 194.

283. White, supra note 89, at 2.

284. Id.

285. Id. 
currently exists raises the costs to borrowers and future lenders. Others may argue that a broad discharge will produce an inappropriate "wealth transfer from those debtors who avoid bankruptcy to those who succumb to it." 286

To be sure, the shifting of costs from debtors receiving a broader discharge to future borrowers in the form of a higher cost of borrowing is a valid concern. However, some observations may help alleviate some of this concern. First, the national economy today is largely dependent upon consumer spending and individuals taking risks by incurring financial indebtedness. ${ }^{287}$ Thus, providing for the broader discharge outlined above will return the overextended debtor to economic productivity. ${ }^{288}$ So long as the externalities produced by a broader discharge do not outweigh the overall benefit to society in having unburdened debtors reintegrated into economic productivity, then a broader discharge is desirable.

Second, given the economic consequences of improvident consumer lending over recent years, the shifting of even greater risk to the lending community will serve a corrective function, preventing such behavior going forward. A number of scholars and commentators over the past decade have reported on the consumer-credit industry preying upon individual consumers who pose a significant risk of default ex ante. ${ }^{289}$ Despite the serious collective risk, the lending community dove in. Perhaps the most strident charge is Professor Lupica's recent indictment of the credit industry:

The credit industry has created the pressure to borrow and knows where consumers' social, economic, and psychological vulnerabilities lie. It knows that consumers tend to discount the long- and short-term consequences of credit use, due to the temporal disconnect between the

286. Hirsch, supra note 248 , at 205 n.94. Richard Posner described this possibility "as a subsidy from the 'prudent' to the 'feckless,' 'a curious basis on which to redistribute wealth!'” Id. (quoting RICHARD A. POSNER, ECONOMIC ANALYSIS OF LAW § 14.4, at 402 (4th ed. 1992)).

287. As Professor Karen Gross noted:

In a capitalistic economy, we want debtors to reintegrate into the system for their sake and our own. For debtors, reintegration allows the taking of new risks. For society, taking risks is exactly what we want individuals and businesses to do. This enables the wheels of commerce to turn; individuals fend for themselves and do not become a drain on scarce societal resources.

GROSs, supra note 38, at 94.

288. See Hallinan, supra note 23, at 62 (noting that in the evolution of the fresh start "was a continuing reliance on the notion that relief measures served the public welfare by restoring the overburdened debtor to economic productivity").

289. See, e.g., Hallinan, supra note 23; Mann, supra note 109; Tabb, supra note 32; Warren, Financial Collapse and Class Status, supra note 36; Warren, supra note 96; Stein, supra note 99. 
charge and receipt of a bill. This discounting and underestimation extends to a number of features of credit use, including present and future balances, the importance of interest rates, the likelihood of a late payment, the speed at which interest accrues, the implications of merely making the minimum payment due; as well as the likelihood of exceeding credit limits, and credit products have been designed to opportunistically exploit these susceptibilities. ${ }^{290}$

A broader discharge will also serve to increase the credit industry's collective incentive to properly monitor their debtors' financial circumstances and ability to repay, and will cause the lending community to be more judicious when deciding to extend credit in the first place. This shifting of risk makes sense from an economic perspective. Creditors are in the best position to evaluate a particular debtor's financial picture and ability to repay, especially if one accepts Professor Jackson's notion of incomplete heuristics. More practically, though, sophisticated consumer lenders have spreadsheets and actuarial tables backed by complex financial models that predict their rate of loss and expected profit margins based upon their portfolio of borrowers. In other words, the prudent lender has already calculated average expected losses and profits ex ante, before ever transacting with a potential customer. So if a creditor lends and the debtor later fails to repay, the creditor is best positioned to bear the consequences of default. ${ }^{291}$

Third, the availability of a discharge — while costs are passed on to those individuals not resorting to the bankruptcy process by those who do-serves as a "compelled purchase of credit insurance by borrowers."292 To the extent that lenders do in fact conduct an individualized risk assessment before lending, theoretically each

290. Lupica, supra note 7, at 585 (footnotes omitted). On this topic, Professor Lupica further argues as follows:

Over the past decades, consumer spending and corresponding indebtedness have provided the central source of fuel for the country's economic growth: as a collective resource, consumers have been the chief target of exploitation by the providers of goods, services, and credit. The enormous investments made in the creation and maintenance of the transformed consumer markets have driven this exploitation. As the supporters of the policies behind the markets' transformation began to affirmatively recognize that high levels of consumer debt were necessary to sustain the markets' unprecedented profitability, a relentless campaign was waged to convince, cajole, and coerce consumers to build their lives around consumption through the routine use of credit. The hegemony of the markets has proven to be a powerful force, inexorably altering cultural norms, consumer behaviors, and attitudes toward debt. Id. at 609 .

291. See Gross, supra note 31, at 134 (arguing this point in support of her own article advocating for a narrow construction of the 1984 Amendments to the Bankruptcy Code).

292. Hallinan, supra note 23 , at 106. 
individual consumer's cost of credit will bear some relation to the potentiality of default and a future bankruptcy filing. ${ }^{293}$ Although economic theorists might be troubled by this shifting of risk through a form of compelled insurance, given the volatility in the national economy and the predatory practices of credit-industry lenders, an ex post facto safety-net for the universe of consumer debtors might not be so offensive after all.

\section{CONCLUSION}

By most observers' accounts, the purpose of enacting BAPCPA was to reduce the number of consumer bankruptcy filings, ${ }^{294}$ and to prevent debtors from abusing bankruptcy law. Congress's experiment has proven to be sorely misguided on both fronts. Although the number of consumer debtors filing for bankruptcy slowed dramatically after the enactment of BAPCPA, largely because thousands of debtors rushed to file before the Amendments became effective on October 17, 2005, the number of people filing for consumer bankruptcy relief has climbed steadily during the past several years, and will continue to do so as the economic recession continues. Further, empirical studies conducted to date completely dispel the fantasy of the abusive debtor attempting to evade his or her indebtedness and shirk financial responsibilities. As perhaps has always been the case, today's typical debtor is burdened with more debt than ever before, and resorts to the bankruptcy process after a cataclysmic event, such as a job loss, divorce, or serious medical problems.

To that end, the purpose of this Article was to accomplish two goals. First, to propose a contemporary justification for the consumer discharge so as to help advance the debate over bankruptcy theory and policy, and to question once again the proper scope of the nation's bankruptcy laws and their place in a modern, credit-based economy. Second, to provide fodder for Congress to rethink many of the legislative changes to the

\footnotetext{
293. In other words:

The risk of each borrower's future inability or unwillingness to pay is transferred to the lender for a premium implicit in the cost of the loan, and the lender pools that risk with other similar risks, thereby spreading losses among borrowers. Moreover, due to the segmentation of the market and the individualization of risk assessment for each transaction, each borrower's premium more or less accurately compensates for the risk transferred, with only minimal opportunities for subsidization by the lender or by other borrowers. 
Bankruptcy Code occasioned by BAPCPA and for the courts to interpret problematic aspects of BAPCPA in a manner that promotes the overall, collective well-being of the flesh and blood debtors that appear in their courtrooms on a daily basis.

A theory of discharge premised upon utilitarian philosophy may have its detractors, and the main counterarguments have been highlighted herein. Perhaps no theory justifying the consumer discharge can garner everyone's support. That said, however, the theory of consumer utility embraces all of the rationales expressed in the past, and incorporates additional justifications that have been previously neglected in the scholarly literature. It is difficult, if not impossible, to forecast whether the proposals advocated by the theory of consumer utility will in fact serve to provide debtors with an improved fresh start. But that uncertainty is no excuse for not attempting to raise debtors out of the mire of debt. However, one thing is certain: BAPCPA serves to impede unjustifiably the fresh start for tens of thousands of deserving debtors, and there is nothing in the legislation that "protects" debtors, despite Congress's rhetoric. The time is ripe for a sweeping reassessment of the nation's bankruptcy laws. If the proposals proffered in this Article are followed, then the borrower shall no longer be a slave to the lender. ${ }^{295}$ 